\title{
A AGRICULTURA ALIMENTAR E O IMPACTO DO CREDITO RURAL SOBRE OS DIFERENTES TIPOS DE PRODUTORES *
}

Norma Montalvo de Soler**

\section{INTRODUÇÃO}

O presente trabalho centraliza sua atenção na análise de uma fração de pequenos produtores não capitalistas ${ }^{\dagger}$ que,por não terem condições potenciais para se inserirem no processo de modernização agricola presente na agricultura brasileira, continuam sendo produtores de alimentos básicos (arroz, milhão, feijão, mandioca etc.), espaço econômico compartilhado também, nas duas últimas décadas, por agricultores capitalistas.

Precisamente, foi a necessidade de compreender o ambiente concorrencial que se observa a nivel de comercialização dos produtos alimentares vinculados à polftica dos preços mínimos de garantia, que nos levou a pesquisar, a nivel da produçẫo e da comercialização, as estratéglas pelas quais optam a empresa agricola capitalista e a pequena produção, e que resultam no aparente nivelamento de ambos os tipos de produtores em termos dos preços minimos para os produtos que cultivam.

A questão que pretendemos desvendar é precisamente o que está por trás dessa aparente nivelação entre ambos os tipos de produtores. O objetivo básico desta indagação é captar a posição ocupada pelo trabalho familiar do pequeno produtor na economia brasileira. Usamos como recurso anal/tico a intervenção do Estado.

Dado que a polftica econômica envolve aspectos alocativos e distributivos de recursos que têm efeitos diferenciais sobre a renda real dos diversos grupos ou

1. ( Versão revisada de um capitulo da tese de Doutorado em Economia titulada "Agrilcultura e Reprodução da Força de Trabalho" apresentada pela autora na UNAM, México DF., 1986.

("*) A autora 6 Mestre em Sociologia (UNB - Brasilia, DF), Doutora em Economia (UNAM - México DF) e trabalha no Mestrado em Sociologia Rural/UFPb.

(1) A Pequena Produção Agricola familiar ou produção não capitalista, se constitui no Brasil numa forma especifica de exploração do trabalho pelo capital, produzida socialmente ao longo do processo histórico do desenvolvimento capitalista no pars. Neste contex to, o pequeno produtor se situa como trabalhador direto subordinado indiretamente ao capital, especificamente de dominaça a do capital sobre o trabalho familiar que é visualizado no marco da relação existente entre o processo global do trabalho e o processo de produção social global, apesar da diferenciąão existente ao interior do segmento pequeno produtor.

Há consenso sobre a diferencią̧ão existente ao interior da pequena produção que vai desde os "pequenos produtores de infrasubsistência", passando pelos "pequenos produtores médios" ate os "pequenos produtores tecnificados ou modernos" integrados às agroindústrias, extratos diferenciais que correspondem a diferentes modalidades de incorporação da pequena produção a produção social global capitalista. Neste trabalho analizamos só um dos estratos da pequena produção, constítuido pela fraçáo de pequenos produtores de alimentos básicos ou pequenos produtores minifundiários de infrasubsisténcia.

\begin{tabular}{|l|l|l|l|l|l|}
\hline Rev. RAIZES & Campina Grande & Ano VI & No 6 & 75 a 106 & Jan.86/mar.88 \\
\hline
\end{tabular}


classes sociais, neste trabalho procuramos entender o impacto diferencial da intervenção estatal, via polftica de crédito agrícola, sobre a empresa agrícola e a pequena produção não capitalista inseridos na produção de alimentos básicos. Particularmente nos propomos compreender como são afetadas as condições de trabalho e de retribuição do trabalho familiar na pequena produção e, deste modo, explicitar em forma aproximada suas condições de reprodução social.

Hlpotetlcamente, sustentamos que o Estado mediatiza neste caso, de uma maneira especifica, a dominação econômica sobre o trabalho familiar, $\theta$, assim, mediatiza não só o incremento da diferenciação existente no interior da pequena produção, mas também a reprodução deste segmento da classe trabalhadora, assim como da burguesia agrária. No entarito, este estudo apenas dá conta da análise da relação econônica que vincula os pequenos produtores ao capital, e não incursiona na anátise de classe propriamente dita.

Este trabalho está baseado integralmente em dados secundários vinculados aos produtores de alimentos no país e à ação do Estado. e pretende levantar as. pectos relevantes que podem ser aprofundados porteriormente em pesquisas de campo.

\section{A AGRICULTURA ALIMENTAR NO BRASIL}

Num pais-em desenvolvimento como o Brasil, onde se prioriza o desenvolvimento do setor industrial, uma das funções que compete à agricultura é apoiar a industrialização na cidade como no campo, pela via da produção de mão-deobra barata, bens para exportação, matérias primas e alimentos baratos. Particularmente esta última função foi assumida por multas décadas, quase que em forma exclusiva, pela pequena produção. Nas duas últimas décadas, uma parte cada vez mais importante da funçăo de garantir o abastecimento de alimentos básicos está sendo compartilhada pela agricultura capitalista, o que parece conseguir-se basicamente através dos benefícios que oferece a política agrícola de crédito, de infraestrutura e de pesquisa agricola, somada ao fato de que esse setor produtor conta com áreas médias e grandes de cultivos, que convergem para aumentar o volume físico da produção - pela via do incremento da produ. tividade e o aumento da superff́cie plantada - para efeito de manter-se em sincronia com os preços de garantia estipulados oficialmente.

Neste trabalho, nos propomos a examinar o processo que assegura esta coexistência, ao mesmo tempo que assegura manter a relativa estabilidade dos preços a nivel da comercialização de produtos básicos. Assim, vamos revisar algumas questões relativas à direcionalidade resultante da polftica agrícola e suas conseqüencias no incremento da polarização interna no setor, influindo na manutenção da rentabilidade das inversões do produto agrícola capitalista e na deterioração das condições de produção e retribuição ao trabalho de uma fração importante dos pequenos produtores ocupados neste sub-setor da agricultura alimentar.

A produção capitalista se distancia, de modo regular, de ramos produtivos que não têm condições de oferecer o nivel de lucro igual ou maior que a taxa média, deixando em geral estes espaços para pequenos produtores não capitalistas que não tềm possibilidades de alcançar nem sequer o correspondente a um 
salário mínimo como retribuição para o trabalho familiar aplicado na produção de um bem. No entanto; nas últimas décadas, observamos na agricultura brasileira a incursão de pequenos e médios produtores capitalistas na agricultura alimentar, isto é, no cultivo de produtos básicos como o arroz e o milho, particularmente na região centro-sul do país. Em tudo isto, o paradoxal é que os preços minimos estipulados para esses produtos - que são não só notadamente baixos quando comparados com os de outros produtos comerciais mas ainda, em certa medida, mínimos a ponto de nem sempre cobrirem os custos da produção - regem indiferenciadamente todo tipo de produtores ${ }^{2}$. Como explicar que o cultivo de produtos alimentares de consumo básico - apesar de não gerar uma taxa de lucro consistente com a taxa efetiva de lucro vigente na economia como um todo e, em particular, no setor capitalista da agricultura - seja um espaço econômico compartilhado simultaneamente por pequenos produtores não capitalistas e por produtores capitalistas?

Consideramos que, no fundo de tal paradoxo, está a intervenção do Estado e, em grau mais desprezivel, a possivel insuficiência da disponibilidade de alimentos provenientes da agricultura não capitalista para um mercado em expansão de produtos que são elementos básicos na reprodução da força de traba. Tho. Na medida em que a política agrícola subsidia fortemente a produção realizada sobre bases capitalistas, cria condições para que o capital, sob um estrito cálculo econômico, invista também em certos ramos aparentemente não rentáveis, como a agricultura alimentar, sem com isso deslocar do espaço produtivo, os pequenos produtores näo capitalistas.

A fim de visualizar este paradoxo, vamos centralizar nossa atenção no campo estritamente econômico da intervenção governamental no setor agrícola, através da análise de suas açōes para reduzir os custos da produção (crédito rural) e de suas ações para estabilizar a renda do produtor rural (polftica de preços mínimos).

O Estado tem uma participação direta no mercado de alimentos hásicos. A ação estatal está orientada a resguardar os preços de um importante conjunto de bens-salário como o feijão, o arroz, o milho e a mandioca. Assim, a ingerência estatal se faz presente na fixação dos preços mínimos de garantia destes produtos básicos. Além disso o Estado amplia sua ação de controle sobre a oferta destes produtos, a fim de evitar a alta dos preços, regulando estes no mercado através do controle dos preços dos produtos básicos e da formação dos estoques reguladores. O Estado aparentemente parece ser eficiente na regulação da linha alimentar, no sentido de ter conseguido, relativamente, controlar as margens de lucro dos produtores de alimentos, procurando manter a competitividade a nivel de mercado. No entanto, a conseqüência dos mecanismos aplicados em sua polftica orientada no setor é regularmente objeto de controvérsias entre os analistas, por seu impacto diferencial nas condições de emprego e distribuição da renda dos ocupados na produção alimentar no setor primário, is to independente-

(2) Um exemplo deste tipo de produto vinculado a pequenos produtores e produtores capitalistas e o arroz, que, no sudeste do Maranhão, é produzido por pequenos produ tores năo capitalistas - posseiros e minifundiátios - com áreas de cultivo menores de 3 ha, $e$ no Rio Grande do Sul, é predominantemente produzido por arrendatários capitalistas, regularmente, em áreas maiores de 10 ha, com o emprego de técnicas modernas. 
mente da importância de certos instrumentos de polltica econômica para conseguir metas de produção e abastecimento.

\section{1) ESQUEMAS ORIENTADOS A REDUZIR OS CUSTOS DE PRODUÇÄO NA AGRICULTURA ALIMENTAR.}

Dado que a Política Econômica para a Agricultura estabelece, por um lado, a política de garantia de preços minimos para certos produtos básicos (arroz, feijão, mandioca e milho), preços estes que são, para a maioria dos produtores (pequenos produtores) ao mesmo tempo o "piso" e o "teto" dos preços recebidos, e, por outro lado, estabelece ainda o controle dos preços dos produtos agrícolas e os estoques reguladores a nive! de comercialização propriamente dita. deduz-se dal que os produtores do setor agro-alimentar atuam em mercados competitivos, com produtos cuja denanda é em certa medida inelástica aos preços. Supõe-se que isto induziria a uma menor rentabilidade dos produtos alimentares, reduzindo os investimentos orientados para estes produtos na agricultura. Mas, se simultaneamente existem mecanismos que viabllizam por um lado, um amplo crédito subsidiado para custeio e investimento, que agem diretamente nos custos de produção agrícola, e, por outro lado, existe também crédito oficial e subsidiado para comercialização dos produtos vinculados à política de preços mínimos (EGF/Empréstimo do Governo Federal administrado pela CEP/ Companhia de Financiamento à Produçãol, indubitavelmente muitos empresários nåo terão inconvenientes em investir no setor agro-alimentar, fazendo de conta que tais controles de preços näo existem ${ }^{3}$.

Desde sua institucionalização em 1965, no quadro de polf́ticas econômicas do país, a política de crédito tem funcionado como principal mecanismo compensatório de custos mais elevados na agricultura nacional, evitando, por um lado, a transferência aos consumidores dos custos adicionais em que incorria o setor e, por outro lado, objetivando a viabilização da competitividade a nível de mercado. Desde meados da década de 60 se utilizou, em forma preponderante, o crédito como instrumento de polftica agrícola, sendo uma característica relevante desta polftica que o controle das taxas nominais de juros sejam mantidas sistematicamente em níveis muito baixos gerando taxas reais negativas ${ }^{4}$. 0 objetivo básico foi expandir a produção e a modernização agrícola. Particularmente generosos foram os incentivos à introdução dos chamados "insumos mo-

(3) SAYAD, Joăo (1979) faz uma exposição formal deste mecanismo de compensação para a agriculțra em geral, partindo da existência do subsidio implícito na taxa de juros. "O subsidio implficito na taxa de juros é considerado um indicador de custo social dos programas de crédito rural. O montante do subsidio transferido para a agricultura é aqui definido como a perda de poder aquisitivo do dinheiro comprometido. Trata-se, portanto, de uma simplificação de problemas, pois o custo social seria dado pelo custo de oportunidades do dinheiro". Citado em CIDADE DE ARAUJO, Paulo Fernando. "O Crédito Rural e sua distribuição no Brasil", in Estudos Econômicos 13 (2) 1982. IPE/ USP. pág. 323 e 324.

(4) "Grosso modo, as taxas reais podem ser estimadas subtraindo-se das taxas nominais de juros, a taxa de inflação". Cf. CIDADE DE ARAÚJO, Paulo Fernando. "O Crédito Rural e sua Distribuição no Brasil". In: Estudos Econômicos. Vol. 13 (2) 1983. IPE/USP, pág. 324. 
dernos na agricultura". Quando aconteceu o primeiro choque do petróleo que elevou o custo dos fertilizantes e herbicidas, o Conselho Monetário Nacional decidiu conceder subsidio equivalente a $40 \%$ do valor dos financiamentos para compensar os agricultores por aquele encargo adicional. Por este mecanismo, papara muitos produtores, mais importante que buscar o aumento da produtividade foi a obtenção do crédito rural. Quanto maior o volume maior a redução dos custos alcançados pela produção ${ }^{5}$.

"Os créditos da operação, ou custeio agropecuário, constituem o melhor exemplo de assistência financeira em termos de oferta oficlal de capital operacional e explicam também a importância dos objetivos a curto prazo que preocupam os homens do governo e interessam aos produtores, especialmente, quando as políticas de preços dos produtos estão sob controle mais ou menos rigoroso (oficiaf) como ocorreu no Brasil. O crescimento real do crédl to de custelo no perfodo $1969-1979$, de $445 \%$ (taxa geométrica de $18,5 \%$ ao ano), é uma amostra do impulso oficial à agricultura. Do total de créclito de custeio, $85 \%$ foi i orientado para as atividades agrícolas, crescimento vertiginoso que passa de $23,3 \mathrm{bi}$ Ihões de cruzeiros em 1969 para 94,3 bilhões em 1978 (a preços de 1978). Em 1979 esta expansão foi mais acelerada" (Cidade de Araújo, P. F.pg. 325). Apesar de que a distribuição deste crédito estivesse centrada principalmente no au. mento de área plantada em soja, trigo ${ }^{6}$, cana de açúcar e não precisamente na produção de produtos básicos alinientares, a expansão desses produtos alimentares se remete, em grande parte, às vantagens gerals implícitas nestes créditos, aproveitadas com habilidade empresarial por produtores capitalistas. O exame da tabela $\mathbf{i}$ - apresenta a participação relativa destes produtos (arroz, milho, feijão, mandiocal no interior do conjunto dos cinco produtos denominados de mercado interno, mostrando nítido declínio, apesar de estar incluído no conjunto 0 trigo ${ }^{7}$. Mas "sem considerar a participação do trigo entre os produtos do mercado interno, em razão de suas características muito peculiares de interven-

(5) Muitas vezes "a generosidade dos subs/dios permitiu o desvio do crédito rural para finalidades diferentes daquilas previstas nos regulamentos. Um exemplo significativo é o subsfdio ao uso de fertilizantes. Esses benefícios estimularam produtores, empresas vendedoras e até gerentes de bancos e extensionistas rurais e forjar operaçóes com objetivo de -. apropriar-se : indevidamente dos favores que estavam sendo concedidos pelo governo". Cf. FERREIRA DA NOBREGA, Mailson. Desafios da Politica Agricola. Ed. Gazeta Mercantil/CNPq, 1985, pág. 61.

(6) "Apenas sete cultivos (Algodão, café, arroz, cana de açúcar, milho, soja e trigo) concentram 3/4 do crédito da operação total. Particularmente a soja e o trigo constituem casos de crescimento at́pico. A soja passa de uma participação relativa no crédito da operaçäo de 3,3\% em 1969 para $19 \%$ em 1979, e o trigo de $5,6 \%$ de 1969 para $10,3 \% \mathrm{em}$ 1979. Ademais, dado que na região sul (particularmente no Paraná) a soja e o trigo formam um sisterna integrado que utiliza os mesmos fatores de produçāo, inclusive terra num dado estabelecimento, indica que alguns agricultores estão sendo duplamente bene. ficiados pelo crédito da operação, is to 6 , produzem intensamente estes produtos com estímulos econōmicos muito especiais". Cf. Ibidem, op. cit. pág. 327.

(7) Incluindo-se o trigo nesta classificação, pretende-se desviar para mais a magnitu de do crédito correspondente a esta categoria de produtos de mercado interno, uma vez que o trigo, por tratar-se de um produ to estratégico, em termos de autosuficiência e segurança nacional, é amplamente beneficiado pelo crédito, tendo, como já mencionamos, a maior participação relativa junto com a soja no perfodo 1969/1979. 
DISTRIBUIÇĀO PERCENTUAL DO CRÉDITO DE CUSTEIO AGRICOLA NO BRASIL segundo grupos de produtos e seus mercados principais.

\begin{tabular}{c|c|c|c|c}
\hline Ano & $\begin{array}{c}\text { Produtos para } \\
\text { mercado interno }\end{array}$ & $\begin{array}{c}\text { Produtos de Exporta- } \\
\text { tação e matérias pri- } \\
\text { mas industriais } \\
\text { (b) }\end{array}$ & $\begin{array}{c}\text { Outros produtos } \\
\text { e operação } \\
\text { (c) }\end{array}$ & $\begin{array}{c}\text { Valor total em } \\
\text { milhões de cru- } \\
\text { zeiros, 1978 }\end{array}$ \\
\hline 1969 & 40,61 & 39,13 & 20,26 & $23.299,7$ \\
1970 & 35.75 & 46,54 & 17,71 & $26.856,1$ \\
1971 & 32,44 & 48,25 & 19,31 & $30.115,0$ \\
1972 & 33,23 & 45,98 & 20,79 & $35.731,6$ \\
1973 & 30,70 & 45,74 & 22,56 & $51.301,5$ \\
1974 & 36,73 & 50.43 & 12,84 & $67.215,6$ \\
1975 & 42,56 & 44,06 & 13,38 & $85.615,8$ \\
1976 & 39,81 & 47,43 & 12,76 & $93.012,0$ \\
1977 & 36,88 & 48,36 & 14,76 & $94.591,0$ \\
1978 & 34,14 & 47.17 & 18,79 & $94.938,2$ \\
\hline
\end{tabular}

- FONTE: Comissão Coordenadora da Política Nacional de Crédito Rural (COMCRED (1970) e Banco Central do Brasil - DERUR (1978 e 1979).

- NOTAS: (a) Arroz, feijão, mandioca, milho e trigo.

(b) Algodão, amendoim, cacau, café, cana de açúcar e soja.

(c) Em outros produtos se destacaram em 1978: batata inglesa $(1,8 \%)$; frutas cítricas $(1,8 \%)$, fumo $(2,2 \%)$ e hortaliças $(1,6 \%)$. Em outras operações se incluem sementes, almacigas com $0,3 \%$ do total em 1978 .

In: CIDADE DE ARAÚJO, Paulo Fernando. Op. cit. 
ção governamental, a percentagem de empréstimo para os quatro produtos básicos alimentícios mostra uma diminuição que chega a ser preocupante. Mais objetivamente a participação caiu de $35,5 \%$ em 1969 para $23,9 \%$ em 1978" (Cidade de Araújo, P. F. pág. 328).

No entanto, esta variação desvantajosa é compensada, como se observará mais adiante, pelos benefícios que oferecem os créditos à comercialização destes produtos básicos vinculados à política dos preços mínimos ${ }^{8}$.

\section{2) ESOUEMAS ORIENTADOS PARA A ESTABILIZAÇÃO DA RENDA DO PRODUTOR RURAL}

Desde que fol instituida no Brasil, a política de estabilizaçäo -- tipo polftica de preços mínimos, estoques reguladores etc. - esteve orientada no sentido de diminuir o risco causado pelas flutuações dos preços. Na área agrícola, foi criada na década de 50 a Comissão (hoje Companhia) de Financiamento à Produção (CFP), empresa pública vinculada ao Ministério da Agricultura responsável pela implementação da Política de Preços Mínimos, orientada e estabilizar a renda ao produtor rural. Esta polftica se operacionaliza através de dois instrumentos:

- As aquisições do Governo Federal (AGF) ${ }^{9}$ instrumento que garante ao produtor rural a compra de seus produtos básicos, a preco mínimo oficlal, em anos de safras abundantes ou de excedentes que não conseguiram colocar a um melhor preco.

- Os empréstimos do Governo Federal (EGF) ${ }^{10}$, são créditos para a comercialização vinculados aos produtos amparados pela política de preços minimos planejados para alcançar dois objetivos: conseguir a estabilizaçăo dos preços para o produtor, promovendo a redução das variações de preços dentro do ano ${ }^{11}$ e melhorar a posição competitiva do

(8) "Preço mínimo é o preço de suporte, de garantia, abaixo do qual o agricultor não deve vender seu produto. Em tese, ele deve situar-se pelo menos ao nivel da média do custo de produção de cada produto nas diversas regiōes do pais". In Polftica de Precos MIni. mos. CFP. Ministério da Agricultura.

(9) "As aquisiçäes do Governo federa! (AGF) consistem na venda pura e simples da produção ao Governo. O Agricultor, uma vez realizada a colheita, deposita-a no armazém, faz a classificąçăo, e, em posse da certidāo de depósito e da classificação correspondente. dirige-se a uma agência do Banco do Brasil, onde realiza a venda e recebe o valor do produto, calculado de acordo com o preço mínimo. As AGF säo importantes, porque, através delas, o Governo confirma seu objetivo de apoiar e garantir o produtor rural. Mas este tern uma desvantagem. Se os preços do mercado sobem apos vendida a produção ao Governo, o agricultor não tem mais como aproveitar da alta". In: Polftica de Garantia de Precos Minimos. CFP. Ministério da Agricultura.

(10) "Os empréstimos do Governo Federal (EGF) consistem em uma espécie de arranjo de precomercializąão da produção ao governo que posteriormente pode ou não concretizer-se em venda. O agricultor, uma vez realizada a safra, deposita no armazém, realiza a classificação e em posse do comprovante correspondente, se dirige à agência do Banco do Brasil. A produção, calculada de acordo com o preço $\mathrm{m}$ (nimo, fica depositada como garantia em empréstimo, isto é, o agricultor não vonde imediatamente seu produ to ao Governo. O Banco the concede o "crédito" e "a quantidade recebida é exatamente igual à 
produtor, possibilitando a melhora da posição de negociação do produtor ${ }^{12}$, em resumo, a CFP é responsável pela fíxação dos preços mínimos e pela formulação das operações do EGF, sendo que a contratação destas operaçōes que caracterizam a assistência financeira direta ao produtor rural, é executada pelo Banco do Brasil e, nas duas últimas décadas, também pelos Bancos Comerciais privados. Os recursos financeiros necessários a estas operações são em grande medida produto das transferências efetuadas pelo Banco Central com base em orçamentos monetários e divida pública.

Desde 1965, incrementaram-se os instrumentos operacionais para conseguir a planejada estabilização da renda do produtor. Por trás deste objetivo, mencionado como básico, está a idéia de criar condições favoráveis ao incremento da produção assim como a de proteger os consumidores das variações violentas de preços. "É preciso evitar que a baixa de preços, provocada pela oferta concentrada no perfodo da colheita, se traduza em desestrmulo às decisões de plantio no perfodo seguinte, que provocaria chóques de oferta com reflexos negativos no abastecimento, nas exportações e na inflação" (Ferreira da Nóbrega, Mailson, pág. 105). No entanto, diversos analistas, entre eles Fernando Homem de Melo, sugeram que "as polfticas de preços mínimos e os estoques reguladores foram incapazes de alterar, de modo significativo a situação de maior instabilidade dos preços dos produtos domésticos-alimentares (...). Igualmente, o impacto da politica de preços mínimos não foi sentido de forma uniforme por produtos por ela contemplados (...). A diferença da soja, o algodão, o amendoim, em que as evidências indicam que essa politica foi decisiva para provocar um crescimento da

que seria recebida na venda. O empréstimo tem um prazo, que pode chegar até onze meses. Se durante o prazo, os preços de mercado se elevam, o agricultor pode voltar ao Banco, pagar a divida e vender o produto, ganhando com a al ta dos preços. Se du rante todo - prazo do empréstimo os preços permanecem baixos, o agricultor não se preocupa, porque se até o final o empréstimo náo for pago, o Governo compra a produção penhorada a divida desaparece automaticamente. Esta é a modalidade, dos EGF com opção de venda ao Governo. Existe outra modalidade, os EGS sem opçäo de venda ao Governo. Nestos caso, o produto pode ficar armazenado na propria fazenda a classificacão oficial do produto é dispensada. Em compensação, o valor do empréstimo não passa de $80 \%$ do preço minimo, e o prazo não excede de 180 dias, ao final dos quais o interessacto tem que pagar a divida, pois o produ to näo é comprado pelo Governo". In: Polltica de Ga rantia de Precios Minimos". CFP. Ministetrio da Agricultura.

$(11)^{\prime \prime}$ A redução das variaçóes estacionais de preços seria contida pela capacidade dos EGF em aumentar a elasticidade da oferta dos produtos agricolas no decurso do calendário comercial, por formação de estoques sob penhor do produto, com remissöes compulsórias distribuldas no tempo, com base a certas regras criadas para "organizar" a entrada e safda dos produtos no mercado (considerando seu respectivo fluxo de consumol. Isto reduziria a variação da distribuição de preços dentro do ano". Cf. AZEVEDO COELHO, Carlos Nayro de. e COELHO DE SOUSA TIMM, Sandra, "Alguns Aspectos do EGF como instrumento operacional da Polltica de Preços Minimos" In: Estudos Econômicos. Vol. 13 (3), 1983. IPE/USP.

(12)"A melhoria na posição competitiva do produtor seria obtida através da natureza mesma dos EGF, já que este ao conceder crédito ao usuário, pocie ser utilizado como uma alternativa à venda imediata do produto na época da colhelta, permitindo ao produtor armazenar temporariamente seu produto e esperar melhores condiçôes de mercado". Ibidem, op. cit. 
oferta, nos casos do arroz, milho e principalmente do feijão e mandloca, essa polftica não alcançcu o objetivo de incentivar a produção". Por muito tempo os preços estipulados para estes produtos básicos foram negativos. A partir de 1982 a CFP tem tentado elevar os preços mínimos para estes produtos a fim de aproximar os preços mínimos estipulados na época da colheita, isto é, tem tentado corrigir esse desnivel existente entre os preços mínimos estipulados oficialmente ao inf́cio do plantio e o valor real destes preços na época da colheita. Naquele ano, o Governo iniciou um processo de correção com base do INPC lindice de Preços ao Consumidor), dos preços mínimos fixados antes do plantio. No entanto, acontece que o preço é corrigido somente até a entrada da safra, permanecendo sobre efeito do desgaste inflacionário durante a perfodo comercial lentresafral.

Entretanto, ainda que todos esses esforços levassem a conseguir a estabi. lidade dos preços ao produtor, estaria sempre muito distante, conforme mostraremos mais adlante, de realizar-se o objetivo registrado na política agrícola, ou seja, de estabilizar a renda do conjunto dos produtores rurais de alimentos básicos, uma vez que o pequeno produtor é discriminado na maioria dos benefícios oferecidos por essa polltica. Alguns aspectos do EGF (Empréstimo do Governo Federal) como instrumento da política de preços mínimos, são de um claro benefício na estratégia da produção empresarial orientada a reduzir os custos eleyados da produção. Como o incremento significativo da taxa de inflação levou automaticamente a um debilitamento crescente do preço mínimo em seu papel de "preço antecipado" ou "seguro de preço", os EGF passaram, em última análise, a serem vistos como um mecanismo de garantia com capacidade inclusive de alterar a própria estrutura competitiva do mercado ${ }^{13}$. Evidantemente este aspecto provocou mudanças no processo de decisão de armazenar dos usuários, já que no final do perlodo comercial uma parte cada vez maior da renda total garantida, passou a depender do tamanho do subsidio. Com isto, o EGF passou a ser visto cada vez mais como uma fonte de recursos subsidiados para utilizar-se nas formas mais variadas (Azevedo Coelho, Carlos N. et alii). Nestes termos, os EGF são vistos como um serviço de armazenagem que aumenta a eficiência das atividades comerciais e financeiras do produtor mais que como mecanismo de garantia do produtor rural. Isto tem maior significado se observamos que apenas uma reduzida fração de produtores rurais, aqueles com certa capacidade empresarial e perfeitamente inseridos no âmbito comercial agrícola, são beneficiados com a concessão de grandes empréstimos dos EGF, permitindo que o importan-

(13) Os EGF não têm o mesmo sentido para os prođiutores rurais e para os industriais que também são beneficiários. Enquanto os produtores rurais procuram obter vantagem da variaçäo sazonal de preço, postergando a venda do produto, o industrial, atuando de forma diferente, tenta antecipar a compra do produto. O EGF, como fator de reduçäo do risco do produ to, tampouco tem o mesmo sentido para ambos as categorias de seus beneficiários, pois enquanto o produtor rural usa o EGF como a forma de reduzir seus custos de produção e o risco relativo do preço esperado (como garantia), o industrial utiliza o empréstimo do EGF apenas para reduzir os cursos de armazenagem. Na expectativa da qu eda do preço do produ to no mercado, ele não usa os EGF. Mas se a expectativa for de alta, usa os EGF de qualquer maneira, para reduzir os custos por meio da capitalização do valor do empréstimo e da diferença entre os juros do EGF os juros do mercado. 
te subsidio seja apropriado por esta minoria junto a terceiros lempresas beneficiadoras e indústrias de processamento) que mais recentemente foram também inclufdas entre os beneficiários dos EGF14. Muitos destes passam a usar o EGF (créditos à comercialização) para reduzir custos de produção por meio da capitalização do valor dos empréstimos, dada a diferença de juros reais. Muitos realizam aplicaçőes a curto prazo no mercado financeiro, já que a taxa de juros é sempre inferior às taxas de juros do mercado.

Os dados da tabela 2 mostram a distribuição do volume do EGF por usuário, produ to e regióes, para o período 1961/1981. Podemos al observar a importância relativa das três categorias de beneficiários (produtores rurais, cooperativas de produtores rurais e terceiros). Vemos, assim, que existe uma diferenca substancial na distribuição dos empréstimos do Governo Federal para a comercialização de produtos amparados pela polftica de preços mínimos, tanto em termos de regiöes, como de produtos. A tendência forte do EGF de que certos produtos se concentram mais nas mãos de alguns tipos de usuários evidencia, de certa forma, a importância de que o produto se destina mormente ao consumo direto, ao beneficiamento ou ao processamento. No Nordeste, observa-se uma forte participaçäo dos beneficiadores no financiamento no caso do arroz e das coperativas, no caso da farinha da mandioca. No caso do milho e do feijão, há uma predominância da participação dos produtores rurais mesmo quando tende a incrementar-se, desde 1981, a participação das cooperativas neste último caso. No centro-sul se observa uma participaçâo agressiva de terceiros no financiamento (beneficiadores e industriais) no caso da mandioca, particularmente no ano de 1981 e das cooperativas, no caso do feijão. No caso do milho, há uma ampla participação dos produtores rurais, incrementando-se também a participação das cooperativas no ano 1981. No caso do arroz, a participaçăo é compartilhada pelas três categorias de usuários, correspondendo em ordem de magnitude aos produtores rurais, às cooperativas e os terceiros, o que, por outro lado, mostra claramente o caráter capitalista da produção deste cultivo na região.

Em resumo, através destes dados, observamos que existem quatro categorias de beneficiários do EGF: produtores rurais, cooperativas de produtores rurais, beneficiadores de produtos agrícolas e processadores de produtos agrícolas. Não há nada nos regulamentos que indique que o subsídio é distribuido seletiva.

(14) "Os EGF ao longo do tempo sofrem modificaçoos da sua linha operacional que permitiu ampliar seu leque de beneficiários, incluindo também as organizações não agrfcolas como beneficiários do emprestimo, tais como os beneficiadores de alguns produtos, por razões operacionais dada a impossibilidade do EGF de armazenar na época da safra e com isso melhorar os preços a nivel do produtos lagroindústrias de óleos, raçbes, alimentos enlatados, etc.). Ao mesmo tempo se passou a permitir aos industriais a substitulção do penhor mercantil (que é exigida no caso de concessão de empréstimos aos produ tores rurais participantes) pelo produto processado. O argumento foi económico: reduzir a capacidade da indústria de benefíciamento por meio dos estoques penhorados pelo inđustrial. E também econômico para o produtor dada a possibilidade de ampliar a melhoria das condiçóes de mercado do produtor na época da safra, via aumento da demanda dos produtos para armazenagem industrial. Em forma adicional, portesiormente se permitiu aos industriais a substituição de penhor mercantil por titulos de curto prazo (...). No caso dos títulos, não apareceu nenhum suporte lógico para a substituição do penhor mercantil (nem operacional nem econômico) que servisse de apoio a fal medida". Cf. Ibidem, op. cit. 
TABELA 2

DISTRIBUIÇÄO DO VOLUME DE EGF *por usuário, produto e regiões

(Em percentagem de toneladas) ${ }^{* * *}$

\begin{tabular}{|c|c|c|c|c|c|c|}
\hline \multirow{2}{*}{$\begin{array}{c}\text { REGIŌES } \\
\text { E } \\
\text { PRODUTOS }\end{array}$} & \multicolumn{3}{|c|}{1971} & \multicolumn{3}{|c|}{198} \\
\hline & Produtos & Cooperativas & Terceiros & Produto & Cooperativas & Terceiros ** \\
\hline \multicolumn{7}{|l|}{ Arroz } \\
\hline Centro-Sul & 44.11 & 21.48 & 34.41 & 52.55 & 31.75 & 15.70 \\
\hline Norte - Nordeste & 12.12 & - & 87.88 & 27.37 & 15.80 & 56.83 \\
\hline Brasil & 41.60 & 19.19 & 38.61 & 51.75 & 31.25 & 17.00 \\
\hline \multicolumn{7}{|l|}{ Fei|jão } \\
\hline Centro-Sul & 30.14 & 69.35 & 0.51 & 27.61 & 67.24 & 5.15 \\
\hline Norte-Nordeste & 97.100 & 3.00 & - & 38.50 & 61.50 & - \\
\hline Brasil & 33.80 & 87.72 & 0.48 & 27.53 & 67.23 & 5.74 \\
\hline \multicolumn{7}{|l|}{ Wilfo } \\
\hline Centro-sul & 80.26 & 3.23 & 90.51 & 50.05 & 3121 & 18,64 \\
\hline Note-Nordeste & 79.50 & 9.16 & 10.28 & 87.17 & 7.49 & 5.49 \\
\hline Brasth & 80.18 & 2.95 & 16.89 & 50.90 & 30.76 & 9.96 \\
\hline \multicolumn{7}{|l|}{ Farinha de Mandioca } \\
\hline Centro-Sul & 47.88 & 12.10 & 39.92 & 10.35 & 1.10 & 88.55 \\
\hline Norte-Nondeste & - & - & - & - & 100.00 & - \\
\hline Brasil & 47.98 & 12.10 & 39.92 & $10.2 \%$ & 2.83 & 87.36 \\
\hline
\end{tabular}

PONTE: CPP/DEFIN/GEOPE.

* Empréstimo do Govemo Federal

* Terceinos: refere-se as beneficladores e processaciores

\% Adapatdo de Carlos Noyo de Azevedo Coelho e Sandra Coelho de Souza Timm (1983). 
mente por tipo de usuário. Tampouco, os dados Indicam diretamente que tipo de produtores estão inseridos como beneficiários dos EGF, entretanto, transcendem certos aspectos circunstanciais que mostram serem os produtores com marcada capacidade empresarial os que usam os EGF, dado que a chave é captar o maior subsfdio possivel. Isto está diretamente vinculado à magnitude do penhor mercantil. Pelo visto, os EGF não melhora o poder de negociação do produtor, pois a estrutura competitiva do mercado do qual depende ou năo funciona (não é viável este tipo de mercado no mundo reall ou quando há certa aproximação, os resultados não são os esperados ${ }^{15}$. Alguns analistas, entre eles João Sayad, indicam que a variação dos preços a nivel de produtor é maior que a variação dos preços a nivel de consumidor, sugerindo que isto é resultado da baixa compectitividade do setor "imposta" pela estrutura concentrada do setor de comercializa. ção.

O preço mínimo, que seria proprlamente o aspecto que incrementaria - poder de negociação dos produtores rurais, ainda se situa abaixo dos niveis correspondentes, pois este seria o fator determinante nas relações de intercâmbio na agricultưra/indústria. Os EGF se apresentam apenas como um serviço de comercialização especifico (oficial) o qual abre um espaço para ganhos "extras" aos produtores rurais beneficiados, que os orientam para reduzir seus custos de produção.

Assim sendo, no Brasil, na área agrícola, salvo os investimentos em estradas, irrigação e, mais recentemente, em redes de armazenagem, pesquisa e extensão rural, a redução dos custos de produção deu-se prioritariamente através dos subsídios impl f́citos nos créditos de investimento, custeio e comercializaçãa. Dado o alto susbisio implícito na taxa de juros (tabela 3), muitos usuários tomam o máximo de crédito que podem e aplicam estes recursos em atividades produtivas. Chega-se assim a uma situação na qual a agricultura comercial passa a depender cada vez mais do crédito para financiar suas atividades, mesmo admitindo-se que é possível que os recursos próprios tenham sido cada vez menos usados na empresa agrícola e orientados para a melhor alternativa de investi. mento dentro e fora do setor, inclusive no mercado financeiro e imobiliário.

A análise feita sobre os diversos tipos de crédito agrícola mostra como através de diversas estratégias os produtores rurais beneficiados com o susbídio implicito nos créditos incrementam seus recursos que se orientam a estabilizar a empresa produtiva através da redução dos custos de produção. Assim, a genero. sidade do susbisio implicito no crédito rural também projetou seus benefícios e um subsetor considerado não prioritário, como a produção agro-alimentar. Estes recursos aproveitados pelos empresários agrícolas junto aos benefícios provenientes de programas de pesquisa existente particularmente no Estado paulista e no Rio Grande do Sul e de obras de infraestrutura, sobretudo de irrigaçåo, foram fatores evidentemente básicos que influenciaram na decisão de investir na

(15) Corro já mencionamos, o armazenamento do produto seu correspondente empréstimo pela operaçâo EGF, se fundermenta na líéia de que, aumentando a demanda para armazenar o produ to na época da safra, o produtor rural terla oportunidade de pôr seu produ to no mercado na entressafra, pois neste perlodo a mercado se torna mais competitivo, com as empresas comerciais e industriais empenhadas em garantir seu abastecimento. Deste modo se transfeririam os beneficios do EGF ao produtor rural. 
TABELA 8

ARROZ: 1$)$ Evoluçẫo da Área Cultivada. Médias Trienais por Estados produtores (1000 Ha). II) Evolução da área cultivada de cada Estado

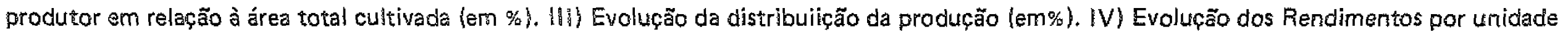
de área $(\mathrm{kg} / \mathrm{Ha})$. Períodos: 1931/1933, 1961/1969 e 1979/1980

\begin{tabular}{|c|c|c|c|c|c|c|c|c|c|c|c|c|}
\hline \multirow[t]{2}{*}{$\begin{array}{c}\text { BRASIL, ESTADOS } \\
\text { E } \\
\text { REGIOES }\end{array}$} & \multicolumn{3}{|c|}{$\begin{array}{l}\text { Evolução da Área Cultìvada } \\
\qquad(1000 \mathrm{ha}) \\
\end{array}$} & \multicolumn{3}{|c|}{$\begin{array}{c}\text { Evoluçõ da Área Cultivada/ } \\
\text { Área total } \\
\text { (\%) }\end{array}$} & \multicolumn{3}{|c|}{$\begin{array}{c}\begin{array}{c}\text { Evoluçäo Distribuição da } \\
\text { Produçẫo } \\
(\%)\end{array} \\
\end{array}$} & \multicolumn{3}{|c|}{$\begin{array}{c}\text { Evolução dos Rendimentos } \\
\text { por Unidade de área } \\
(\mathrm{kg} / \mathrm{ha})\end{array}$} \\
\hline & $1939 / 33$ & $1867 / 69$ & $1979 / 80$ & $1931 / 33$ & $1967 / 69$ & $1979 / 80$ & $1931 / 33$ & $1967 / 69$ & $1979 / 80$ & $1931 / 33$ & $1967 / 69$ & $19979 / 80$ \\
\hline io Grande do Sul & 119.4 & 394.3 & 562.0 & 14.8 & 8.9 & 9.6 & 17.2 & 19.8 & 22.8 & 1,663 & 3,334 & 3,533 \\
\hline Mato G & 6. & 228,7 & $1,361.6$ & 0. & & 23.4 & 0.8 & 5 & 18.0 & 1,351 & 1,572 & 1,142 \\
\hline Goiás & 49.2 & $854, \frac{3}{3}$ & 1.066 .7 & 6.7 & 19.1 & 18.2 & 6.3 & 16.8 & 15.3 & 1,479 & 1,302 & 1,244 \\
\hline Maranhão & 23.8 & 536.4 & 921.3 & 2.9 & 12.4 & 15.8 & 2.3 & 10.4 & 13.6 & 1,122 & 1,274 & 1.276 \\
\hline Minas Gerais & 113.3 & 806.6 & 550.7 & 14.8 & 18.1 & 9.4 & 13.2 & $\lceil 5.3$ & 8.6 & 1,330 & 1,252 & 1,354 \\
\hline Paraná & 10.6 & 388.7 & 357.2 & 1.3 & 8.7 & 6.1 & 0.9 & 6.3 & 5.1 & 995 & 1,078 & 1,294 \\
\hline São Paulo & 191.6 & 721.1 & 300.2 & 47.9 & 16.2 & 5.2 & 49.2 & 13.4 & 4.2 & 1,460 & 1,232 & 1,212 \\
\hline Santa Cátarina & 21.7 & 79.9 & 135.5 & 2.6 & 1.8 & 2.3 & 1.9 & 3.2 & 3.9 & 1,033 & 2,652 & 2,540 \\
\hline Pará & 12.1 & 67.3 & 124.8 & 1.5 & 1.5 & 2.1 & 1.3 & 1.0 & 2.1 & 1,262 & 987 & 1,421 \\
\hline Piaur & 6.4 & 81.8 & 171.8 & 0.8 & 1.8 & 2.9 & 0.7 & 1.6 & 1.8 & 1,195 & 1,257 & 571 \\
\hline NORDESTE & - & - & - & - & - & - & 6.9 & 15.8 & 16.5 & - & - & - \\
\hline CENTRO-SUL & - & - & - & - & - & - & 91.5 & 82.9 & 79.5 & - & - & - \\
\hline BRASIL & 813.4 & $4,456.9$ & $5,835.9$ & - & - & - & - & - & - & 1,421 & 1,484 & 1,489 \\
\hline
\end{tabular}

FONTE: Tabela estruturada em base aos dados elaborados por F. Homem de Melo.

IN: O Problema Alimentar no Brasil. 
produção de bens como arroz e o milho, por parte de produtores capitalistas localizados na regiaao centro-sul. Assim, concretamente, a produção empresarial de produtos alimentares básicos é rentável. Mas os empresários certamente permanecerão neste espaço econômico enquanto continue efetiva a taxa média de lucro ${ }^{16}$. Contrariamente, os cultivos alimentares, que para uma fração majoritária de pequenos produtores se perfila como a base de sua reprodução social, não é rentável. Via de regra, o crédito rural no Brasil segue a produção comercial, a nivel de regiões, produtos e tipos de produtores.

O crédi to rural subsidiado, mesmo sendo um instrmento de compensação pelos custos elevados da produção no setor agrícola, da forma como é aplicado, $\dot{e}$ um instrumento concentrador da renda, injusto deste ponto de vista social. "Ao alcançar só aquele que tem condições de acesso a uma instituição financeira, termina por disfarçar problemas estruturais sérios (...). Em algumas regiões do pals, é comum verem-se agricultores de baixa renda financiados por intermediários e agiotas, numa situação inaceitável que exige pronta e permanente atuação do governo" (Ferreira da Nóbrega, Maison, págs. 11, 77 e 79). O subsidio via crédito é, pois, um instrumento seletivo desde que é distribuído segundo a capacidade de produção, sendo praticamente discriminados os pequenos produtores. Como o risco envolvido nas atividades agrícolas é sempre muito al to, os requisitos exigidos para a obtenção de empréstimo bancário sâo também maiores.

Em geral, exigem-se como garantias de empréstimo agrícola a hipoteca da terra ou penhor da safra, levando-se em consideração ainda o tamanho do estabelecimento a magnitude da safra. Por sua vez, os bancos integrantes do sistema nacional de crédito rural (SNCR) tendem a selecionar seus clientes, principalmente pelo nivel de riscos das garantias apresentadas e sua situação de liquidez. Os requisitos implicam, na prática, exclusão do crédito rural oficial aos pequenos produtores, que não podem satisfazer tais exigências. "O financiamento da produção dos estabelecimentos muito pequenos tropeça com dificuldades muito especiais neste estrato de área. Uma delas é a garantia do crédito. A grande maioria dos pequenos produtores não tem acesso, por exemplo aos empréstimos do governo federal (EGF) por não poder satisfazer uma das exigências para a concessão de empréstimo, que é o penhor da safra. Parte significativa da produção destes agricultores se destina ao seu consumo e, portanto, sob o ponto de vista do produtor não é penhorável, já que se destina à sua própria subsistência. O penhor da safra representa em termos pessoais, um custo mais elevado para a

(16) O que acontecerá quando mude a orientação da polftica agrícola? Dado o esgotamento de um processo de colocação de recursos, via emissão de moeda e divida pública, orientados a prover o setor rural de crédito subsidiado, o Conselho Monetário Nacional (Resolução n. 833 de 09/06/83) estabel ece a redução progressiva do subsidio creditício entre 1983 e 1985, o qual só permaneceria para as Regiões Norte e Nordeste. Não obstante os encargos financeiros do crédito rural variarão segundo o comportamento da inflacão, o que corresponde a implantar, dezoito anos após, a sistemática imaginada no Proje to de Lei de Crédito Rural do Presidente Castelo Branco, cujas disposiçóes a respeito da correção monetária foram, como se observou, eliminadas no substitu tivo apresentado pelo Congresso Nacional. Igualmente, como medida compensatória, o Governo decidiu: eliminar praticamente todos os controles de preços dos produtos agrfcolas exceto para leite e açúcar, e a fixação de preços mínimos passou a ser realizada da forma mais realista. Cf. FERREIRA DA NOBREGA, Mailton. Op. cit. págs. 77,79 e 11. 
agricultura de subsistencia que para a agricultura comercial" (Dos Santos Cuntha, Aécio). Com efeito, sendo o pequeno produtor caracterizado por sua fragilidade econômica, muitos deles chegam com dívidas a necessidades, já antes da safra. Muitos deles esperam, com a venda da safra, poder reiniciar um novo ciclo produtivo. De modo que, se hipoteticamente o pequeno produtor fosse favorecido por um empréstimo do EGF, de imediato uma fraçấo do valor recebido se orientaria para o pagamento de dívidas adquiridas, sendo que outra se orientaria para cobrir a subsistência regular da famflia e os gastos para um novo ciclo produtivo. Portanto, ao não poder incrementar tal empréstimo por meio da capitalização do valor recebido, como o faria em seu lugar um empresário, năo terá condições de pagar o empréstimo adquirido antes de seu vencimento, para poder assim vender seu produto em melhores condiços na entressafra. Nestes termos, apesar do "aperto" financeiro que sofre, não é permitido ao pequeno produtor aproveitar as oportunidades de ganhos "extra", que os EGF oferecem aos produtores rurais num perfodo em que uma superprodução na época da sarra pressiona a baixa dos preços, ao contrário do empresário que se beneficia com o abastecimento da liquidez temporal que the proporcionam os EGF. Não é que o pequeno produtor não seja um "sujeito de empréstimo". Pelo contrário, dada sua precariedade constante, o pequeno produtor sempre precisa de crédito, de pequenos empréstimos aos quais recorre regularmente quando necessário. Só que comumente $o$ pequeno produtor é considerado pelas entidades financeiras como "cliente de alto risco" dadas as Infimas garantias que apresenta. Além disso, o círculo de credores ao qual se vê obrigado a recorrer the impớe os mais altos juros que existem na sociedade. Para o pequeno produtor só resta o crédito caro, mesmo nas poucas vezes que consegue um empréstimo bancário, para ele resulta mais caro que para os demais, dada a escassa magnirude do crédito solicitado e o custo relativamente elevado dos encargos financeiros cobrados pelos bancos filiados ao Sistema Nacional de Crédito Rural.

Como vemos, a esquema do EGF nåo funciona na prática para o pequeno produtor. Ante um panorama tão restrito na área de financiamento oficial, ao pequeno produtor não resta outra alternativa que usar o instrumento das $A G F$, que praticamente é usado quase que exclusivamence pelos pequenos produtores. Através deste instrumento da polfuca de preços minimos, uma parcela do financiamento à comercialização canalizada pela CfP chega até o pequeno produtor, que é na realidade um participante importante no abastecimento de produtos alimentares de consumo básico no mercado interno. No entanto, este mecanismo dos AGF, é acionado o menos possfvel, já que o interesso do Governo não é formar estoques inecessários, nem ocupar-se do problema de uma produção tão dispersa como a do subsetor pequeno produtor, que a fim das contas, dificilmente interferiria negativamente nas variaçôs do mercado agro-alimentar. Para o pequeno produtor "os prepos săo dados" (preços mínimos) e dada sua condição de pequeno produtor dirsto, não tem possibilidade de ultrapassar este nivel. Regularmente é o pequeno produtor quem fica numa posiçäo bem mais vulnerável num contexto onde o setor comprador de produtos básicos toma-se naturalmente menos competitivo. ante uma sítuação de alta oferta por safras abundantes, o comprador atua tranquilamente, porque tem certeza de comprar tudo o de que precisa ao preço minimo. Ante a baixa oferta por safra escassa, 
tampouco tem que correr muito, porque mesmo oferecendo precos maiores que o minimo estipulado oficialmente tem a alternativa de aplicar nos EGF e assim reduzir os custos de armazenamento por meio da capitalização do valor do empréstimo e da diferença de juros do EGF e do mercado. A situação do pequeno produtor está continuamente comprometida: tanto os prejudica uma safra abundante quanto uma produção escassa. Em casos de excesso de produção, os preços de seus produtos baixam violentamente. Aqui, possivelmente, o pequeno produtor deve tratar de vender seu produto ao governo (AGF). Mas, nem sempre compensa ao pequeno produtor direto levar o produto até os depósitos das AGF na cidade, particularmente se estes ficam muito distantes de sua unidade produtiva, pois isto implica um gasto adicional que pode não compensar economicamente. Assim, se vê obrigado a vender seu produto na localidade ao fazendeiro ou a outros intermediários, mesmo a preços abaixo do preço mínimo. Nos casos de safra escassa, os preços se elevam, mas também dificilmente os pequenos produtores são favorecidos, tanto porque os que mais lucram nesta conjuntura são os intermediários, quanto porque, às vezes, ao fim da colheita, os preços não são tão altos como os esperados.

Mesmo enfrentando toda esta série de dificuldades dentro da politica agricola, o pequeno produtor se beneficia com o preço mínimo. O problema constante para os pequenos produtores está vinculado ao risco do resultado final de sua atividade produtiva, uma vez que da quantidade produzida em termos de valor depende a subsistência familiar e a possibilidade de reiniciar ou nåo um novo ciclo produtivo. Sua fragilidade econômica é tal, que para a maioria dos pequenos produtores de subsistência, está próxima a possibilidade familiar de ter alguma renda ou de enfrentar a fome. Nestes condições, o preço mínimo, apesar de não ser alto para os produtos alimentícios de consumo básico, é ainda - mecanismo que garante, mesmo parcialmente, o poder de négociação do pequeno produtor. Além disto, o preço mínimo é de um nítido caráter social, porque a diferença do crédito rural alcança todo tipo de produtor, inclusive os pequenos produtores que, regularmente, não tem acesso aos financiamentos bancários oficiais e privados. Um bom preço mínimo seria uma compensação significativa, particularmente para o pequeno produtor que está discriminado pelos créditos oficiais.

O sistema credit́fcio, da forma como está formulado, näo é neutro. Legalmente se estipula que o crédito é generalizado e se reitera que este privilegia os pequenos produtores. Mas na realidade foi formulado sem levar em conta a heterogeneidade da estrutura agrária a produtiva nem a diferenciaçäo existente no interior do próprio segmento pequeno produtor. Em 1979 através da resolução 546, o Banco Central determinou que pelo menos $25 \%$ dos empréstimos do sistema nacional de crédito rural fossem dados aos mini e pequenos produtores. Em todo caso, antes de registrar insistentemente a necessidade de fazer chegar o crédito aos pequenos produtores, os órgãos oficiais encarregados deveriam tentar vias espec/ficas (talvez programas de produção espec/ficos para pequenos produtores vinculados a créditos especif́icos, adequados às condiçöes concretas deste tipo de produtoresl de créditos, dentro do conjunto do sistema de créditos agropecuários, para fazer chegar realmente a este tipo de produtor o apoio oficiat à produção. Nenhum país pode negligenciar apoio a um subsetor maioritário 
do setor agrícola, que antes de tudo, como no cano dos pequenos produtores do Brasil, está comprometido com atividades que não só constituem fonte de vida para essa população mas ainda, mesmo em situação de crise do subsetor como a que atualmente atravessa, contribuem mais para o produto total que o estrato de estabelecimentos superiores a 1.000 hectares (tabela 4). Os dados desta tabela ${ }^{17}$ mostram que a política de crédito, além de näo alcançar o objetivo explicito de tornar o crédito dispensável aos pequenos produtores, está orientada para os médios e grandes produtores. Ao analisar os dados sobre o valor dos créditos por instituições oficiais e outras, assim como sua distribuição nos diversos estratos da área, observamos que, em 1975, em um extremo, os pequenos estabelecimentos com menos de 10 hectares - que representaram $52,1 \%$ do número total, $2,8 \%$ da área total e $14,8 \%$ da produção total - receberam $2,7 \%$ dos créditos oficiais. Em outro extremo, os grandes estabelecimentos com mais de 1.000 hectares, que representavam $0,9 \%$ do número total de estabelecimentos, $42,9 \%$ da área total e $13,5 \%$ da produção total, receberam $22,2 \%$ do crédito oficial. Finalmente, o nível de concentração do crédito é tẫo alto que, apesar da grande expansão dos financiamentos que ocorrera a partir de 1966/1967, em 1976, 85,6\% dos estabelecimentos não foram alcançados pelo crédito rural institucional e informal.

De outra perspectiva, a tabela 5 , mostra o problema distributivo baseado no Censo de 1970 e 1975. Apesar de que todos os estratos de área receberam mais crédito em 1975, os estratos com menos de 10 hectares, receberam somente $\mathrm{Cr} \$ 0,06$ por cruzeiro de valor da produção, enquanto que os estabelecimentos maiores que 10.000 hectares receberam $\mathrm{Cr}$ \% 0,75 por cruzeiro do valor da produção. Tudo isto indica que os programas de crédito tendem a causar uma distribuição concentrada do financiamento. No fundo do problema distributivo, está o fato de que no subsídio implicito ao crédito rural estão aplicados recursos públicos orientados para objetivos sociais, mas que, finalmente, resultam em custos sociais muito al tos para o país.

A análise do crédito rural dá a impressão de que o pequeno produtor se encontra em um ćrculo vicioso. Frente à concentração na distribuição do crédito, as inovações tecnológicas e outros aspectos da produção, estimulados ou, pelo menos, facilitados pelo crédito rural, não se difundem entre os pequenos produtores. Isto reduz sua capacidade competitiva no uso dos fatores, suas possibilidades de desenvolvimento e acumulação de riquezas. Tal situação expressa uma rigidez estrutural para a qual contribui, também, a política agrícola.

Embora o conjunto de aspectos até aqui analisados demonstre que, por mais deteriorados que sejam os termos do intercâmbio indústria/agricultura alimentar, os empresários agrícolas conseguem retornos em torno da taxa média de lucro, que the permite permanecer no espaço da produção agro-alimentar. Este sucesso, em grande parte, obedece ao fato de que os produtores capitalistas têm compensações no processo produtivo através dos subsíduos implícitos nos

(17) Paulo Fernando Cidade de Araujo faz um estudo sobre o crédito rural é sua distribuição no Brasil, usando estatisticas oficiais do Banco do Brasil a partir de 1969. Além das informaçöes do SNCR, usa também os dados dos Censos Agropecuários de 1970 e 1975. Os dados a que nos referimos remetem a essa pesquisa. 
CRÉDITO RURAL E DISTRIBUIÇÃO DOS ESTABELECIMENTOS RURAIS DO BRASIL, segundo o tamanho e sua participação na área total e produção total. 1970 e 1975

\begin{tabular}{|c|c|c|c|c|c|c|c|c|c|c|c|}
\hline \multirow{3}{*}{ Estrato de tamanho $(\mathrm{Ha})$} & \multicolumn{4}{|c|}{ CENSO 1970} & \multicolumn{7}{|c|}{ CENSO 1975} \\
\hline & \multicolumn{2}{|c|}{ Estabelecimento } & \multirow{2}{*}{$\begin{array}{l}\text { Área } \\
(\%)\end{array}$} & \multirow{2}{*}{$\begin{array}{c}\text { Produção } \\
\text { (\%) }\end{array}$} & \multicolumn{2}{|c|}{ Estabelecimento } & \multirow{2}{*}{$\begin{array}{l}\text { Ärea } \\
(\%)\end{array}$} & \multirow{2}{*}{$\begin{array}{c}\text { Produção } \\
(\%)\end{array}$} & \multicolumn{3}{|c|}{$\begin{array}{c}\text { Distribuição dos emprés- } \\
\text { timos segundo a } \\
\text { fonte }\end{array}$} \\
\hline & Número & $(\%)$ & & & Número & $(\%)$ & & & $\begin{array}{c}\text { Oficiais } \\
(\%)\end{array}$ & (\%) & $(\%)$ \\
\hline Menos de 10 & 2.519 .630 & 51,1 & 3,1 & 17.8 & 2.601 .860 & 52.1 & 2.8 & 14.8 & 2.7 & 5.7 & 3.2 \\
\hline 10 a menos de 100 & 1.934 .392 & 39.3 & 20.4 & 40.0 & 1.899 .949 & 38.0 & 18.6 & 38.5 & 28.6 & 29.0 & 28.7 \\
\hline 100 a menos de 1000 & 414.746 & 8.4 & 37.0 & 29.3 & 446.170 & 8.9 & 35.7 & 32.9 & 46.5 & 34.6 & 44.6 \\
\hline 1000 a menos de 10.000 & 35.425 & 0.7 & 27.2 & 10.7 & 39.648 & 0.8 & 27.8 & 12.2 & 19.2 & 22.2 & 19.7 \\
\hline 10.000 a mais & 1.449 & 0.1 & 12.3 & 1.9 & 1.820 & 0.1 & 15.1 & 1.3 & 3.0 & 8.5 & 3.8 \\
\hline De tamanho não declarado & 18.377 & 0.4 & - & 0.3 & 4.805 & 0.1 & - & 0,3 & - & - & - \\
\hline TOTAL & 4.924 .019 & 99.9 & 100.0 & 100.0 & 4.993 .252 & 100.0 & 100.0 & 100.0 & 100.0 & 100.0 & 100.0 \\
\hline
\end{tabular}

Fonte: Censos Agropecuários: 1970 e 1975 - FIBGE.

In: CIDADE DE ARAÜJO, Paulo Fernando, op. cit., p. 340. 
TABELA 5

VALOR DOS EMPRÉSTIMOS RURAIS E SUA RELAÇÃO COM O NÚMERO DOS ESTABELECIMENTOS E VALOR DA PRODUÇÄO DOS ESTRATOS DA ÁREA TOTAL BRASIL: 1970 e 1975

\begin{tabular}{l|c|c|c|c|c|c}
\hline \multirow{2}{*}{ ESTRATO } & \multicolumn{2}{|c|}{$\begin{array}{c}\text { Valor total dos em- } \\
\text { préstimos (em milhões } \\
\text { de cruzeiros) (a) }\end{array}$} & \multicolumn{2}{|c|}{$\begin{array}{c}\text { Valor médio dos em- } \\
\text { préstimos por esta- } \\
\text { belecimentos (em } \\
\text { cruzeiros) (a) }\end{array}$} & $\begin{array}{c}\text { Relação entre valor dos } \\
\text { empréstimos e valor } \\
\text { da produção }\end{array}$ \\
\cline { 2 - 7 } & 1970 & 1975 & 1970 & 1975 & 1970 & 1975 \\
\hline Menos de 10 & 1.696 .8 & 3.263 .0 & 673.4 & 1.254 .2 & 0.05 & 0.06 \\
10 a menos de 100 & 10.211 .6 & 28.982 .1 & 5.279 .1 & 15.262 .2 & 0.14 & 0.19 \\
100 a menos de 1000 & 12.895 .1 & 45.094 .9 & 31.091 .0 & 101.071 .5 & 0.24 & 0.35 \\
1000 a menos de 10.000 & 4.820 .0 & 19.914 .7 & 136.058 .0 & 502.289 .6 & 0.24 & 0.42 \\
10.000 a mais & 1.230 .3 & 3.826 .5 & 849.287 .4 & 2.102 .458 .3 & 0.36 & 0.75 \\
\hline
\end{tabular}

FONTE: Censos Agropecuários: 1970 \& 1975 - FIBGE

NOTA: (a) = Em valores aproximados. Valores corrigidos pelo indice " $Z$ " da FGV, com base em 1978. In: CIDADE DE ARAÚJU, Paulo Fernando. Op. cit. pág. 342. 
créditos de custeio e investimento, e levam vantagem no processo de comercialização através das operaçóes do EGF.

Com efeito, se, em principio, os preços mínimos de garantia são os mesmos para todo tipo de produtores rurais de alimentos básicos, o fato de que estes preços, para os pequenos produtores, sejam o "teto" e ao mesmo tempo, no methor dos casos, o "piso" dos preços recebidos, os diferencia dos produtores capitalistas, que têm oportunidade de melhorar sua posição competitiva e, assim, de obter prȩ̣os mais altos para seus produtos. Isto acontece nåo só porque têm recursos para transportá-los até áreas com melhores mercados e preços, mas sobretudo, porque têm a possibilidade de utilizar os EGF, que podem utilizar como uma alternativa à venda imediata de seu produto na época da safra. Isto tem maior significaçẫo se considerarmos que estas diferenças, no fundo, ainda encobrem - como já mencionamos - outra diferença também existente a nível da produção, no processo de redução dos custos que o apoio institucional propicia para os produtores capitalistas e praticamente exclui, dessa oportunidade, os pequenos produtores.

Esta diferénça seria, pois, a condição estrutural de coexistência de ambas as formas produtivas em um mesmo espaço econômico, onde a permanência do empresário se condiciona a conseguir a taxa média de lucro e a do pequeno pro. dutor à possibilidade de conseguir os meios necessários à sua reprodução como pequeno produtor. $E$ possível que muitos pequenos produtores não alcancem nem uma retribuição semelhante ao salário mínimo vigente.

Assumindo-se que os "preços minimos" são aqueles que o pequeno produtor recebe pela venda de seus produtos e comparando a distâncla existente entre a magnitude média dos preços $m$ inimos e a média dos preços recebidos por todos os produtores de alimentos básicos (incluindo-se os pequenos produtores), observamos que, no caso do feljão (Tabela 6), para o período 1967/1984, a média anual de preço mínimo, correspondente a $60 \mathrm{~kg}$ deste produto é de $\mathrm{Cr} \$ 5.548,00$ (preços de 1982), enquanto que a média anual dos preços recebidos por todos os produtores ascencle a $\mathrm{Cr}$ (5.146,00. No caso da mandioca-raiz (Tabela 7), para o perfodo 1975/1984, a média anual do preço mínimo de uma tonelada deste produto é de $\mathrm{Cr} \$ 4.659,00$, enquanto que a média anual dos preços recebidos pelo conjunto de produtores é de $\mathrm{Cr} \$ 13.832,00$. Isto indicaria por um lado, que a síruação dos pequenos produtores é a mais precária dentro do conjunto de produtores de alimentos básicos. Por outro lado, este baixo nível de retribuição ao trabalho do pequeno produtor näo deixa de exercer pressão sobre os preços dos alimentos básicos, reduzindo o preço médio recebido pelo conjunto dos produ. tores destes produtos, o qual possivelmente dificulta sua expansão.

Em geral, a produção agro-alimentar não consegue ainda consolidar-se. Pelo contrário, há indícios de que a produção se encontra estagnada a nível de todo o país. O exame da evolução dos quatro cultivos alimentares básicos (tabelas $8,9,10$ e 11) mostra que todas elas declinam em seu rendimento por hectare entre os triênios 1931/1933 e 1979/1980, o que indica sua condição de produtos - em média - pouco rentáveis, sobretudo nos casos do feijão e da mandioca. Este é um aspecto significativo que repercute particularmente nas condições de trabalho e reprodução social dos pequenos produtores, que são os maiores responsáveis pela produção destes produtos. $O$ arroz e o milho, em certas 
TABELA 6

FEIJÃO. Evolução dos Preços Mínimos. Praços Recebidos pelos produtores e Preços ao atacado.

A preços constantes (1). Base: Dezembro de 1982. Perfodo: 1967 a 1984. Cz\$ $60 \mathrm{~kg}$ (2)

\begin{tabular}{|c|c|c|c|c|c|c|c|c|}
\hline \multirow{2}{*}{ ANOS } & \multirow{2}{*}{$\begin{array}{c}\text { Preços Minimos } \\
\text { Feijầo } \\
\text { Centro-Sul (Cr })\end{array}$} & \multicolumn{4}{|c|}{ Preços Recebidos pelos Produtores } & \multicolumn{3}{|c|}{ Preços ao Aitacado } \\
\hline & & Paraná & Sta. Catarina & Bahia & Média & São Paulo & R. de Janeiro & Média \\
\hline 1967 & 3,284 & 3,305 & 3,602 & 4,752 & 3,886 & - & - & - \\
\hline 1968 & $\$ .192$ & 3,076 & 2,711 & 4,547 & 3,445 & - & - & - \\
\hline 1969 & 3,253 & 5,483 & 3,835 & 7,616 & 5,645 & 8,689 & 6,805 & 7,747 \\
\hline 1970 & 4,071 & 4,951 & 5,428 & 8,832 & 6,337 & 6,840 & 8,047 & 7,193 \\
\hline 1971 & 4,178 & 4,724 & 4,421 & 7,755 & 5,633 & 6,628 & 5,927 & 6,377 \\
\hline 1972 & 3,762 & 4,688 & 3,756 & 5,359 & $4.60 \mathrm{I}$ & 7,788 & 5,068 & 6,426 \\
\hline 1973 & 3,699 & 10.440 & 8,295 & 13.651 & 10,795 & 16,339 & 13,121 & 14.730 \\
\hline 1974 & 4,382 & 7,169 & 8,551 & 9,070 & 7,597 & 10,074 & 9,036 & 9,555 \\
\hline 1975 & 4,346 & 6,552 & 4,329 & 8,924 & 8,602 & 11,265 & 6,478 & 8,871 \\
\hline 1976 & 4,128 & 11.025 & 6,772 & 17.483 & 11,760 & 18.962 & 8,645 & 13.403 \\
\hline 1977 & 4.979 & 7,960 & 6,735 & 12.929 & 9.208 & 12,984 & 7,954 & 10,469 \\
\hline 1978 & 4,563 & 5,465 & 5,167 & 7,536 & 6,089 & 9,294 & 7,293 & 8.293 \\
\hline 1970 & 4,328 & 6,105 & 4,994 & 8,899 & 6.666 & 4,370 & $7,3 \mathrm{B3}$ & 8,376 \\
\hline 1980 & 5,136 & 自1, 486 & 9.994 & 15,192 & 12,224 & 19,537 & 11,371 & 13,954 \\
\hline 1981 & 6,512 & 11.818 & 9,834 & 15,668 & 12,440 & 19.966 & 12,873 & 14,919 \\
\hline 1982 & 6,394 & 5,606 & 5,535 & 7,839 & 6,327 & 7,966 & 6,115 & 7,040 \\
\hline 1983 & 5,614 & 7,416 & 5,393 & 10,481 & 7,763 & 11,547 & 6,708 & 10,124 \\
\hline 1984 & 5,949 & 10.176 & 5,861 & 5,922 & 10,653 & 17,839 & 8,721 & 13,280 \\
\hline
\end{tabular}

Média atual 1967/1984: 5,548,00

$8.146,0$

FONTE: Elaboração própria realizada a partir das seguintes fontes de dados: CFP/MA. Dados sobre preços mInimos. A preços nominais a constantes; FGV. Dados sobre preços recebidos pelos produtores. A preços nominais e constantes; SIMA. Dados sobre preços ao atacado. A preços nominais e constantes.

(-) sem informaçäo.

(1) Preços reais deflacionados com base no 1GP/Dl. FGV/lndice: Conịuntura Econômica. Coluna 2.

(2) Os valores $C_{r} 60 \mathrm{~kg}$ referem-se as respectivas médias aritméticas anuais. 
TABELA 7

MANDIOCA-RAIZ e FARINHA DE MAND1OCA. Evolução dos Preços Mínimos. Preços recebidos pelos produtores Preços ao atacado. A preços constantes (1). Base: Dezermbro de 1982. Periodo: 1967 a 1984. Cz $\$ 60 \mathrm{~kg}$ (2).

\begin{tabular}{|c|c|c|c|c|c|c|c|c|c|}
\hline \multirow[t]{2}{*}{ ANOS } & \multirow{2}{*}{$\begin{array}{r}\text { Preços Mínimos } \\
\text { Mandioca-raiz } \\
\text { Centro-Sul(Cr\$) }\end{array}$} & \multicolumn{4}{|c|}{$\begin{array}{c}\text { Precos Recebisos pelos produtores } \\
\text { Mandioca-Raiz }\end{array}$} & \multicolumn{4}{|c|}{$\begin{array}{l}\text { Preços ao Atacado } \\
\text { Farinha de mandioca }\end{array}$} \\
\hline & & Bahia & Ceará & Pernambuco & Média (4) & Recife & Bahia & Ceará & Média (6) \\
\hline $1967(7)$ & - & - & - & 11,768 & - & - & - & - & - \\
\hline 1968 & - & 6,194 & - & 9,687 & - & - & - & - & - \\
\hline 1969 & - & 6,560 & - & 7,688 & - & - & - & - & - \\
\hline 1970 & - & 8.383 & - & 9,877 & - & - & 4.764 & - & - \\
\hline 1971 & - & 13,140 & - & 10,995 & - & - & 5,735 & - & - \\
\hline 1972 & - & 12,048 & - & 9,232 & - & - & 3,218 & 2,699 & - \\
\hline 1973 & - & 10,877 & - & 7,681 & - & - & 3,018 & 2,568 & - \\
\hline 1974 & - & 10,879 & 10,017 & 8,211 & - & - & 4,388 & 2,850 & - \\
\hline 1975 & 4.907 & 15,071 & 13,247 & 14,705 & 14,341 & 6,496 & 3,833 & 3,245 & 4,525 \\
\hline 1976 & 4,697 & 31,205 & 17,192 & 16.303 & 21,567 & 7.432 & 4.959 & 3.805 & 5.399 \\
\hline 1977 & 4,997 & 26,183 & 13,196 & 12,664 & 17,346 & 4,621 & 4.320 & 2,628 & 3,656 \\
\hline 1978 & 5,009 & 26,292 & 8,372 & 11,780 & 15,481 & 4.180 & 3,577 & 1,970 & 3,242 \\
\hline 1979 & 4,420 & 15,708 & 10,336 & 13,550 & 13,198 & 4,791 & 4.414 & 2,786 & 3,998 \\
\hline 1980 & 4.414 & 13,577 & 14,488 & 19,389 & 15,818 & 7.144 & 5.877 & 3,772 & 5,598 \\
\hline 1981 & 4,079 & 12,947 & 13,644 & 16.323 & 14.305 & 6.905 & 5.535 & 4.152 & 5.531 \\
\hline 1982 & 5,277 & 8,866 & 8,980 & 11,484 & 9,777 & 5,139 & 3,726 & 2,690 & 3,852 \\
\hline 1983 & 4,723 & 5,933 & 7,628 & 7,608 & 7,056 & 4,168 & 3,013 & 2,290 & 3,157 \\
\hline $1984(8)$ & 4,077 & 7,674 & 8,977 & 11,645 & 9,432 & 8,492 & 5,068 & - & 6,780 \\
\hline
\end{tabular}

Média Anual 1975/1984 - 4.659,00

$13,832,00$

FONTE: Elaboraçăo própria realizada a partir das seguintes fontes de dados: CFP/MA. Dados sobre preços minimos. A preços nominais e constantes; FGV. Dados sobre preços recebidos pelos produtores. A preços nominais e constantes; SIMA. Dados sobre preços ao atacado. A preços nominais e constantes.

(-) sem informação.

(1) Preços reais deflacionados com base no IGP/DI. FGV/Indice: Conjuntura Edonômica. Coluna 2.

(2) Os valores $\mathrm{Cr} \$ 60 \mathrm{Kg}$ teferem-se as respectivas médias aritiméticas anuais. 
TABELA3

VALOR DA SUBVENÇÃO EMBUTIDA NA TAXA DE JUROS DO CRÉDITO RURAL, RELAÇÄO COM O VALOR DOS FINANCIAMENTOS E PILCF (PRODUTO INTERNO LIOUIDO A CUSTO DOS FATORES) DO SETOR PRIMÁAIO (Cr\$MILHÕES CORRENTES). BRASIL:Período 1969 a 1979

\begin{tabular}{|c|c|c|c|c|c|c|c|c|}
\hline ANO & $\begin{array}{l}\text { PILcf SE- } \\
\text { TOR PRIMA- } \\
\text { RIO }\end{array}$ & $\begin{array}{l}\text { VALOR DOS } \\
\text { FINANCIA- } \\
\text { MENTOS }\end{array}$ & $\begin{array}{l}\text { TAXA DE } \\
\text { INFLA. } \\
\text { ÇAO }\end{array}$ & $\begin{array}{l}\text { TAXA NO- } \\
\text { MINAL DE } \\
\text { JUROS }\end{array}$ & $\begin{array}{c}\text { TAXA REAL } \\
\text { DE } \\
\text { JUROS }\end{array}$ & $\begin{array}{l}\text { VALOR DE } \\
\text { SUBVEN- } \\
\text { CEAO }\end{array}$ & $\begin{array}{l}\text { SUBVENÇÄO } \\
\text { PILCF SE- } \\
\text { TOR PRIMÁRIO }\end{array}$ & $\begin{array}{l}\text { SUBVENÇÃO } \\
\text { VALOR Fl- } \\
\text { NANCIAMENTO }\end{array}$ \\
\hline 1969 & 14.336 & 6.489 & 20,8 & 18,0 & $-2,32$ & 150 & 0,010 & 0,023 \\
\hline 1970 & 17.127 & 9.428 & 19,8 & 17,0 & $-2,34$ & 220 & 0,013 & 0,023 \\
\hline 1971 & 23.973 & 12.870 & 20,4 & 7,0 & $-2,82$ & 362 & 0,015 & 0,028 \\
\hline 1972 & 30.560 & 18.669 & 17,0 & 15,0 & $-1,71$ & 319 & 0,010 & 0,017 \\
\hline 1973 & 44.270 & 30.334 & 15.1 & 15,0 & $-0,08$ & 24 & 0,0005 & 0,001 \\
\hline 1974 & 65.657 & 48.273 & 28,7 & 15,0 & $-10,64$ & 5.136 & 0,078 & 0,106 \\
\hline 1975 & 87.820 & 89.997 & 27,7 & 15,0 & $-9,95$ & 8.954 & 0,101 & 0,099 \\
\hline 1976 & 137.703 & 130.226 & 41,3 & 15,0 & $-18,61$ & 24.235 & 0,176 & 0,186 \\
\hline 1977 & 236.849 & 165.858 & 42,7 & 15,0 & $-19,41$ & 32.193 & 0,136 & 0,194 \\
\hline 1978 & 320.670 & 233.942 & 38,7 & 15,0 & $-17,09$ & 39.980 & 0,125 & 0,171 \\
\hline 1979 & 520.608 & 448.731 & 77,2 & 38,0 & $-22,12$ & 99.259 & 0,191 & 0,221 \\
\hline
\end{tabular}

Nota: $r=\frac{i-t, \text { sendo } r}{i+t}=$ taxa real de juros, $i=$ taxa nominal de juros e $t=$ taxa de inflação.

Fonte: Fundação Getúlio Vargas \& Banco Central do Brasil (dados primários(apud PINTO (1981:8)

1n: Maria Ignés S. Paulilo. "Crédito Agrícola e Pequena Produção". Trabalho apresentado ao XI Encontro Anual da ANPOCS. 1987 
TABELA 9

FEIJÄO: 1) Evolução da Área Cultivada. Médias Trienais por Estados produtores (1000 Ha). I1) Evolução da área cultivada de cada Estado produtor em relação à área total cul tivada (em \% . lil) Evolução da distribuição da produção (em \%). WV Evolução dos Rendimentos por unidade de área $(\mathrm{kg} / \mathrm{Ha})$ ). Periodos: 1931/33, $1961 / 89$ e $1979 / 1980$.

\begin{tabular}{|c|c|c|c|c|c|c|c|c|c|c|c|c|}
\hline \multirow[t]{2}{*}{$\begin{array}{c}\text { BRASIL, ESTADOS } \\
\text { EREGIOES }\end{array}$} & \multicolumn{3}{|c|}{$\begin{array}{c}\text { Evolução da Area Cultivada } \\
(1000 \text { ha) }\end{array}$} & \multicolumn{3}{|c|}{$\begin{array}{c}\text { Evoluçäo da Área Culçivada/ } \\
\text { Area total }(\%) \\
\end{array}$} & \multicolumn{3}{|c|}{$\begin{array}{c}\text { Evoluçẫo Distribuição da } \\
\text { Produçăc (\%) }\end{array}$} & \multicolumn{3}{|c|}{$\begin{array}{l}\text { Evolução dos Rendimentos } \\
\text { por Unidade de área }(\mathrm{kg} / \mathrm{ha})\end{array}$} \\
\hline & $\mid 1931 / 33$ & $1967 / 69$ & $1979 / 80$ & $1931 / 33$ & $1967 / 69$ & $1979 / 80$ & $1931 / 33$ & $1987 / 69$ & $1979 / 80$ & $1931 / 33$ & $1987 / 89$ & $19979 / 80$ \\
\hline Paraná & 11.8 & 659.9 & 780.8 & 4.5 & 18.1 & 17.5 & 5.1 & 20.3 & 22.3 & 1,117 & 786 & 518 \\
\hline Minas Gerais & 103.0 & 497.8 & 552.3 & 14.8 & 13.6 & 12.2 & 17.5 & 10.7 & 12.5 & 1.190 & 549 & 492 \\
\hline São Paulo & 264.5 & 243.2 & 420.3 & 36.5 & 6.7 & 9.4 & 32.7 & 5.4 & 12.3 & 869 & 573 & 634 \\
\hline Bahia & 20.1 & 240.8 & $4,15.4$ & 2.8 & 6.6 & 9.3 & 3.0 & 7.3 & 19.1 & 1,010 & 777 & 580 \\
\hline Ceará & $i 2.9$ & 353.2 & 341.2 & 1.8 & 8.7 & 7.7 & 1.9 & 7.9 & 3.8 & 1,028 & 572 & 241 \\
\hline Pernambuco & 14.7 & 256.2 & 292.3 & 2.0 & 7.0 & 6.6 & 2.2 & 5.6 & 5.5 & 1,136 & 557 & 409 \\
\hline Paraíba & 11.9 & 179.0 & 243.1 & 1.7 & 4.9 & 5.4 & 1.7 & 3.8 & 2.2 & 878 & 539 & 194 \\
\hline Santa Catarina & 14.3 & 112.3 & 234.9 & 2.0 & 3.1 & 5.3 & 2.0 & 4.4 & 7.2 & 998 & 1,000 & 663 \\
\hline Rio Grande do Sul & 161.1 & 266.6 & 191.9 & 22.3 & 7.3 & 4.3 & 22.4 & 8.9 & 5.0 & 870 & 850 & 566 \\
\hline Goiás & 21.8 & 145.9 & 174.0 & 3.0 & 4.0 & 3.0 & - & - & - & 1,000 & 828 & 297 \\
\hline Mato Grosso & 2.6 & 59.5 & 110.6 & 0.4 & 1.6 & 2.4 & 0.4 & 3.9 & 3.2 & 980 & 799 & 624 \\
\hline NORDESTE & - & - & - & - & - & - & 13.3 & 29.0 & 31.0 & - & - & - \\
\hline CENTRO-SUL & - & - & - & - & - & - & 86.4 & 70.0 & 67.3 & 978 & 704 & 484 \\
\hline BRASIL & 717.7 & $3,649.0$ & $4,479.0$ & - & - & - & - & - & - & - & - & - \\
\hline
\end{tabular}

FONTE: Tabela estruturada em base zos dados elaborados por F. Homem de Melo.

IN: O Prodelema Alimentar no Brasil. 
TABELA 10

MIILHO: I) Evolução da Área Cultivada. Médias Trienais por Estados produtores (1000 Ha). II) Evolução da área cultivada de cada Estado produtor em relação à área total cultivada (em \%). lll) Evolução da distribuiçăo da produção (em \%). IV) Evolução dos Rendimentos por unidade de área $(\mathrm{kg} / \mathrm{Ha})\}$. Perióodos: 1931/33, $1961 / 69$ e $1979 / 1980$.

\begin{tabular}{|c|c|c|c|c|c|c|c|c|c|c|c|c|}
\hline \multirow[t]{2}{*}{$\begin{array}{c}\text { BRASIL, ESTADOS } \\
\text { E REGIOES }\end{array}$} & \multicolumn{3}{|c|}{$\begin{array}{c}\text { Evolução da Area Cultivada } \\
(1000 \mathrm{ha})\end{array}$} & \multicolumn{3}{|c|}{$\begin{array}{c}\text { Evolução da Área Cuitivada/ } \\
\text { Área total }(\%)\end{array}$} & \multicolumn{3}{|c|}{$\begin{array}{l}\text { Evolução Distribuição da } \\
\text { Produção }(\%)\end{array}$} & \multicolumn{3}{|c|}{$\begin{array}{l}\text { Evolução dos Rendimentos } \\
\text { por Unidade de área }(\mathrm{kg} / \mathrm{ha} \text { ) }\end{array}$} \\
\hline & $1931 / 33$ & $1967 / 69$ & $1979 / 80$ & $1931 / 33$ & $1967 / 69$ & $|1979 / 80|$ & $1931 / 33$ & $1967 / 69$ & $1979 / 80$ & 1931/33 & $\mid 1967 / 69$ & $1979 / 80$ \\
\hline Paraná & 197.8 & $1,434.2$ & $2,141.9$ & 5.2 & $\$ 5.1$ & 18.7 & 5.3 & 19.4 & 15.4 & 1,449 & 1.729 & 2,166 \\
\hline Rio Grande do Sul & 780,3 & $1,675.7$ & $1,824.4$ & 20.7 & 17.6 & 15.9 & 22.6 & 17.1 & 13.5 & 1,560 & 1,300 & 1,375 \\
\hline Minas Gerais & 825.2 & $1,565.4$ & $1,670,5$ & 22.2 & 16.5 & 14.5 & 22.5 & 16.4 & 25.4 & 1,453 & 1,340 & 1,680 \\
\hline Santa Catarina & 126.7 & 500.1 & $1,060.1$ & 3.4 & 5.3 & 9.2 & 3.5 & 7.0 & 12.6 & 1.461 & 1,786 & 2,217 \\
\hline São Paulo & $1,000.0$ & $1,322.8$ & $1,042.3$ & 28.3 & 14.0 & 9.1 & 26.2 & 17.8 & 12.9 & 1,338 & 9,708 & 2,244 \\
\hline Goiás & 113.3 & 401.1 & 821.4 & 3.0 & 4.2 & 7.2 & - & - & - & 1,753 & 1,560 & $2, \uparrow 49$ \\
\hline Maranhão & 9.4 & 300.9 & 466.7 & 0,3 & 3.2 & 4.1 & 0.2 & 1.6 & 1.4 & 1,175 & 697 & 556 \\
\hline Bahia & 28.6 & 291.8 & 441.4 & 0.8 & 3.1 & 3.8 & 0.8 & 2.2 & 1.8 & 1,469 & 955 & 726 \\
\hline Ceará & 28.3 & 461.4 & 404.1 & 0.8 & 4.9 & 3.5 & 0.7 & 3.2 & 0.8 & 1,384 & 890 & 349 \\
\hline Pernambuco & 121.7 & 322.5 & 300.9 & 3.2 & 3.4 & 2.6 & 2.8 & 2.2 & 0.9 & 1,247 & 863 & 517 \\
\hline Parafba & 9.7 & 242.1 & 284.4 & 0.3 & 2.5 & 2.5 & 0.2 & 1.6 & 0.4 & 1,206 & 844 & 269 \\
\hline Mato Grosso & 8.1 & 127.9 & 183.3 & 0.2 & 1.3 & 1.6 & 0.2 & 1.3 & 1.6 & 1,368 & 1,283 & 1,597 \\
\hline NORDESTE & - & - & - & - & - & - & 6.5 & 13.3 & 8.4 & - & - & - \\
\hline CENTRO-SUL & - & $\theta$ & - & - & - & - & 93.2 & 86.3 & 92.6 & - & - & - \\
\hline BRASIL & $1,747.9$ & 9.507 .6 & $1,482.8$ & - & - & - & - & - & - & 1.434 & 1,344 & 1,592 \\
\hline
\end{tabular}

FONTE: Tabela estruturada em base aos dados elaborados por F. Homem de Melo.

IN: O Problema Alimentar no Brasil 
TABELA 11

MANDIOCA: 1) Evolução da Area Cultivada. Médias Trienais por Estados produtores (1000 Ha). ll) Evolução da área cultivada de cada Estado produtor em relação à área total cultivada (em \%). III) Evoluçäo da distribuiçăo da produção (em \%). (V) Evolução dos Rendimentos por unidade de área (kg/Ha)). Periodos: 1931/33, 1961/69 e 1979/1980.

\begin{tabular}{|c|c|c|c|c|c|c|c|c|c|c|c|c|}
\hline \multirow[t]{2}{*}{$\begin{array}{l}\text { BRASIL, ESTADOS } \\
\text { E REGIOES }\end{array}$} & \multicolumn{3}{|c|}{$\begin{array}{c}\text { Evolução da Area Cultivada } \\
(1000 \text { ha) }\end{array}$} & \multicolumn{3}{|c|}{$\begin{array}{c}\text { Evolução da Área Cultivada/ } \\
\text { Area total }(\%) \\
\end{array}$} & \multicolumn{3}{|c|}{$\begin{array}{c}\text { Evoluçấo Distribuição da } \\
\text { Produção }(\%)\end{array}$} & \multicolumn{3}{|c|}{$\begin{array}{l}\text { Evolução dos Rendimentos } \\
\text { por Unidade de área (kg/ha) }\end{array}$} \\
\hline & $1931 / 33$ & $1967 / 69$ & $1979 / 80$ & $1931 / 33$ & $1967 / 69$ & $1979 / 80$ & $1931 / 33$ & $1967 / 69$ & $1979 / 80$ & $1931 / 33$ & $1967 / 69$ & $1979 / 80$ \\
\hline Maranhão & 6.3 & 205.0 & 356.9 & 2.9 & 6.5 & 12.6 & 1.9 & 6.5 & 12.6 & 22,467 & 9,161 & 8.893 \\
\hline Bahia & 26.4 & 217.5 & 294.0 & 7.2 & 13.1 & 18.5 & 3.6 & 13.1 & 18.5 & 17,723 & 17,360 & 15,902 \\
\hline Rio Grande do Sul & 85.6 & 276.2 & 192.3 & 30.0 & 12.0 & 9.0 & 13.3 & 12.0 & 9.0 & 15,366 & 12,553 & 17,767 \\
\hline Pernambuco & 41.3 & 140.7 & 187,5 & 14.3 & 5.0 & 7.6 & 7.2 & 5.6 & 7.6 & 17,127 & 11,571 & 10,320 \\
\hline Ceará & 9.3 & 115.1 & 165.5 & 3.3 & 6.2 & 4.7 & 2.2 & 6.2 & 4.7 & 23,147 & 15,755 & 7,234 \\
\hline Minas Gerais & 5.2 & 120.6 & 126.1 & 1.8 & 7.1 & 7.5 & 1.3 & 7.1 & 7.5 & 24,407 & 17,015 & 15,000 \\
\hline Pará & 6.6 & 74.1 & 110.4 & 2.3 & 3.0 & 5.8 & 1.7 & 3.0 & 5.8 & 25,063 & 11,699 & 13,297 \\
\hline Santa Catarina & 10.0 & 130.0 & 98.0 & 3.4 & 9.6 & 6.7 & 1.8 & 9.6 & 6.7 & 17,322 & 21,388 & 17,229 \\
\hline Paraná & 14.2 & 94.7 & 44.0 & 4.9 & 6.7 & 3.1 & 2.5 & 6.7 & 3.1 & 17.761 & 20.448 & 17,869 \\
\hline São Paulo & 21.1 & 105.5 & 25.6 & 7.4 & 6.9 & 2.0 & 4.0 & 6.9 & 2.0 & 18,914 & 18,751 & 20,020 \\
\hline Golás & 5,3 & 73.6 & 22.3 & 1.9 & 4.5 & 1.3 & - & 4.5 & 1.3 & - & 17,531 & 14,278 \\
\hline NORDESTE & - & - & - & - & - & - & 21.6 & 42.4 & 53.9 & - & - & - \\
\hline CENTRO-SUL & - & - & - & - & - & - & - & 52.7 & 35.4 & - & - & - \\
\hline BRASIL & 237.2 & $1,980.7$ & $2,099.6$ & - & - & - & - & - & - & - & 14,565 & 12,020 \\
\hline
\end{tabular}

FONTE: Tabela estruturada em base aos dados elaborados por F. Homem de Melo.

IN: O Problema Alimentar no Brasil. 
áreas, escapam a esta regra e podem manter sua discreta presença junto a outros cultivos comerciais. Apesar de tudo, em geral, a produção cresce em vários Estados e regiōes no período mencionado. Comumente este incremento se observa no Nordeste, pois na região Centro-Sul regularmente descresce dado o processo recente de substituiçáa de culturas alimentares por novos produtos, mesmo que, $\mathrm{em}$ volume produzido, estas regiöes ainda continuam registrando a maior participação sobretudo na produção do milho $(92,6 \%)$ e arroz $(79,5 \%)$ em 1979 / 1980.

Por outro lado, observa-se que a polftica econômica se preocupa com o abastecimento de alimentos, praticamente só a nivel da comercialização, mas não existe um programa ou mecanismos de promoção à produção. Isto é particularmente grave, porque o problema alimentar a nivel rural é ao mesmo tempo um problema de ocupação/emprego, particularmente quando se observa que os principais responsáveis por sua produção são ainda os pequenos produtores (Tabela 12). De fato, em certas áreas, uma fração importante de pequenos produtores está inserida em ocupações que não the permitem ter uma renda familiar necessária à sua reprodução social. Esta situação é evidente entre os produtores minifundistas de alimentos básicos, na região $N E$, o que os obriga a distribuir seu tempo de trabalho entre atividades como pequenos produtores a atividades de assalariamento fora da parcela familiar como forma de viabilizar sua reprodução como pequenos produtores.

\section{ALGUMAS CONSIDERAÇŐES FINAIS}

Ao abordar a análise da agricultura de alimentos básicos, espeço econômico compartilhado por produtores capitalistas e não capitalistas, observamos como apesar da aparente nivelação entre ambos os tipos de produtor, em termos dos preços mínimos para os produtos que geram, os preços de mercado destes produtos e a presença de certos mecanismos econômicos e extraeconômicos, mediatizados pelo Estado, perm/tem aos empresárlos agrícolas obter lucros, enquanto que os pequenos produtores não conseguem ultrapassar os limites da simples subsistência.

Os dados mostram que a concorrência do abastecimento de produtos alimentares básicos, por produtores capitalistas e não capitalistas, a preços mínimos, se dá porque a empresa agrícola capitalista ten condiçóes de concorrer porque seu diferencial de produtividade - resultante do uso de tecnologia moderna, na medida em que é subsidiada via créditos a juros negativos para Investimento e custeio, na medida em que o Estado proporciona a infraestrutura necessária a seu desempenho, ao reduzir os custos de produção dos produtos alimentares -, compensa-se a exploração permanente do trabalho familiar e a falta de lucro nos preços dos produtos alimentares provenientes da pequena produção agrícola familiar.

Se esta situação se cria e se mantêm graças à transferência de recursos públicos, via crédito, para os produtores capitalistas, descriminando-se destes benef́cios os pequenos produtores, o Estado é um dos elementos importantes que mediatiza não só o incremento da diferenciação existente no interior da pequena produção familiar, mas também a reprodução das classes no campo: da 
TABELA 12

BRASIL - Pessoal Ocupado na Agricultura por Atividade - 1980

\begin{tabular}{c|r|r|r|r|r}
\hline Atividades & Total & $\begin{array}{c}\text { Responsável e membros } \\
\text { não remunerados dá fa- } \\
\text { mfllia }\end{array}$ & $\begin{array}{c}\text { Permanentes } \\
-\end{array}$ & $\begin{array}{r}\text { Empregados } \\
\text { Temporários }\end{array}$ & $\begin{array}{c}\text { Parceiros } \\
\text { e outras } \\
\text { condições }\end{array}$ \\
\hline 1. Mercado Interno & 7.908 .049 & 6.751 .294 & 226.851 & 744.431 & 145.473 \\
Arroz & 1.657 .027 & 1.348 .136 & 83.083 & 198.616 & 27.192 \\
Feijão & 2.360 .342 & 2.014 .147 & 60.574 & 233.626 & 51.995 \\
Mandioca & 1.527 .840 & 1.265 .358 & 71.327 & 145.741 & 45.414 \\
Batata lnglesa & 1.899 .200 & 1.755 .562 & 20.364 & 199.161 & 14.012 \\
Banana & 87.666 & 59.981 & 5.973 & 20.435 & 1.277 \\
2. Exportação & 3.651 .555 & 2.011 .222 & 787.994 & 674.947 & 177.392 \\
Soja & 824.439 & 619.298 & 82.092 & 114.369 & 8.690 \\
Amendoim & 58.353 & 41.941 & 2.750 & 13.044 & 618 \\
Laranja & 177.005 & 110.471 & 35.971 & 26.556 & 4.007 \\
Algodão & 490.841 & 350.263 & 28.264 & 93.646 & 18.668 \\
Cana de Açúcar & 678.460 & 163.918 & 306.425 & 201.449 & 6.668 \\
Cacau & 340.659 & 154.977 & 112.752 & 69.845 & 3.085 \\
Café & 1.081 .798 & 570.354 & 219.740 & 156.038 & 135.666 \\
3. Outros & 4.028 .120 & 3.054 .203 & 358.245 & 511.779 & 103.892 \\
4.PECUÁRIA & 5.576 .011 & 3.826 .136 & 757.563 & 836.723 & 155.589 \\
5. TOTAL & 21.163 .735 & 15.642 .855 & 2.170 .654 & 2.767 .880 & 582.346 \\
\hline
\end{tabular}

FONTE: FIBGE - Tabulações especiais do Censo Agropecuário de 1980.

In: GARCIA GASQUES, José e PAIVA, Adelina - 1984. 
pequena produção como segmento da classe trabalhadora e da burguesia agrária. No entanto, o desempenho da agricultura alimentar capitalista, que se apresenta como um sucesso econômico, na medida em que é gerada artificialmente, sua manutenção depende, em grande parte, de que o governo continue sustentando os créditos, a juros negativos, tal como se concretizou durante a década de 70 (ver tabela 3). Em dezembro de 1979 se inicia uma mudança de critérios no sistema nacional de créditos agrícolas: $24 \%$ de juros positivos para os pequenos produtores e $33 \%$ para médios e grandes produtores. Desde 1980 novas mudanças no sistema de créditos se sucedem até hoje, elevando cada vez mais o taxa de juros paralelo a uma taxa de inflação que também é alta. Isto está afetando seriamente os diversos ramos da produção agrícola capitalista. Tudo indica que nestes últimos anos se reduziu consideravalmente o ritmo de compra de tecnologia e insumos modernos e até da substitição de peças de máquinas. Dado que esta tecnologia foi concebida e produzida para contextos sócio-econômicos de países avançados, quando implantada nos mesmos padrões na realidade brasileira é cara e parece improvável que em forma privada esta possa ser financiada na mesma magnitude do crescimento registrado na década de 70 . E al, como fica a problemática da produção de alimentos básicos no Brasil?

De todo modo, esta questão surge da análise feita sobre a situação criada e os objetivos perseguidos pelo governo, na ótica que tem prevalecido nas politicas agrícolas no Brasil deste 1967, mas não porque ela seja, propriamente, a grande questäo. Essa idéia de que é possivel baixar os preços dos produtos básicos so nivel do conșumidor simplesmente com uma expansão da oferta - via estimulos de crédito rural subsidiado e com garantia de preços mínimos - é um erro derivado de considerar em vigor a velha lei da oferta e demanda que supõe flexiveis os preços dos produtos agricolas.

É mais, a idéla de expandir a produção para incrementar o abastecimento de alimentos a preços baixos, por esssa via, fica só nos planos, uma vez que os reais beneficiários dos créditos subsidiados foram os grandes proprietários que são os que tiveram acesso à maior parte desse dinheiro barato e aplicaram em tecnologia e insumos modernos, em terras e outros negócios. Mas, os maiores beneficiários foram as agroindústrias, particularmente as que produzem máquinas e insumos para a agricultura, porque asseguraram grandes lucros e partir do setor agricola modernizado que se constitui num mercado efetivo para seus produtos tão caros.

A questão alimentar é muito complexa e extrapola, em muito, a própria problemática da agricultura alimentar que aliás continua intacta.

Há indícios de que neste último qüinqüênio tem-se freiado a produção de básicos no campo, ao mesmo tempo que a importação destes produtos tem crescido. Pelo demais, a importação de básicos ao estar sempre associada a uma política de privilégio e susb/dio ao consumo urbano não chega ao meio rural. Essa polftica esquece o problema de deterioração crescente das dietas rurais.

Precisamente ao analisar a problemática camponesa conjuntamente com a problemăfica da produção de alimentos de origem agrícola, mostra-se que esta última, se bem a nivel urbano criataliza-se mais como um problema de abastecimento, a nível rural é ao mesmo tempo, um problema de ocupação, de emprego produtivo, que na forma como se efetiva atualmente, compromete seriamente as 
condições de reprodução de amplos segmentos da classe trabalhadora rural. A impossibilidade de lograr a subsistência, não só pela insuficiência dos recursos disponlveis para produzir, mais ainda pela impossibilidade de reter o valor do produzido - ao ser expropriado pelos canais comerciais, financeiros e de politica econômica - afeta diretametne as condiçốes de vida da maioria das famillias camponesas.

Abrumados pela situação de pauperização, grande parte destes pequenos produtores de alimentos básicos, na busca de complemento de seus meios de sobresistência, invadem o mercado de trabalho regional (como o do Nordeste) pressionando a baixa dos salários reais no campo, que historicamente, sempre foram os mais baixos entre os setores. Deste modo, a ameaça de carências críticas se expande a toda a força de trabalho agrícola nas regiōes menos desenvolvidas do país, como no Nordeste e áreas de antiga ocupação agrícola onde este tipo de pequenos produtores minifundiários, produtores de alimentos básicos, se concentram em espaços considerados "bolsões de subsistência".

\section{BIBLIOGRAFIA}

BATRA, Armando - La Exploración del Trabajo campesino por el Capital. Ed. Macehual S.A., México, 1979.

CASTRO, Ana Celia et alii - Evolução recente e situação atual da Agricultura Brasileira. Ed. Binagri, 1979.

CASTRO DE REZENDE, Gervásio - "Estructura Agraria, Produção e Emprego no Nordeste". In:Pesquisa e Planejamento Econômico 9 (1) 1979.

CFP/MA - Seminário de Política Agrícola. Coletânea de Artigos Técnicos. Coleção Análise e Pesquisa, Vol. 25, Brasil, 1982.

CFP/MA - Seminário de Polftica Agrícola. Coleção Análise e Pesquisa, Vol. 15 1982.

CIDADE ARAÜJO, Paulo Fernando - "O crédito rural e sua distribuição no Brasil". In: Estudos Econômicos, Vol. 13 (2). 1983. IPE/USP.

DOS SANTOS CUNHA, Aécio - "Instrumentos da Política Agrícola no Brasil. Pontos para Debate". In: Coleção Análise e Pesquisa. Vol. 25, 1982, CFP/MA.

FERREIRA DA NÓBREgA, Mailton - Desafios da Política Agrícola. Ed. Gazeta Mercantil/CNPq, 1985.

FIGUEIREDO, Vilma - "O trabalhador rural e a modernização da agricultura". In: Revista Brasileira de Tecnologia, Vol. 15 (4), 1984.

FURTADO, Celso - Não à recessão e ao desemprego. Ed. Paz e Terra, 1983.

GARCIA LOUREIRO, Ma. Rita - "Cooperativismo e reprodução camponesa" In: Loureiro, Ma. Rita (Org.) Cooperativas Agricolas e Capitalismo no Brasil. Ed. Cortez. 1981.

GASQUES, José G. y PAIVA, Adelina - Transformações da Agricultura, Pro* cessos de Produção e Emprego. Trabalho apresentado no "XII Encontro Nacional de Economia. São Paulo, 1984". (mimeo). 
GASQUES, José G y GEBARA, J.J., ZOCOLLER, M.M. - Salários, Relação de Trocas e Emprego na Agricultura. Trabalho Apresentado no "XI Encontro Nacional de Economia". Belém, dezembro de 1983.

GRAZIANO DA SILVA, José - A Modernização Dolorosa. Ed. Zahar.

HOMEM DE MELO, Fernando - O Problema Alimentar no Brasil. A Importância dos Desequillbrios Tecnológicos. Ed. Paz e Terra. 1983.

HOMEM DE MELO, Fernando - "A Política Econômica e a Pequena Produção Agrícola". In:Economia Agricola. Ensaios. IPE/USP, 1982.

KAUTSKY, Karl - La cuestión agraria. Ed. Siglo XXI, 1974.

KAGEYAMA, Angela e GRAZIANO DA SILVA, José -- "Produtividade emprego na agricultura brasileira", In: Desenvolvimento capitalista. N. 2 , Ensaios sobre a crise. Edit. Brasiliense, 1983.

LENIN, V. I. - El desarrollo del capitalismo en Rusia. Ediciones en Lenguas Extranjeras, Moscú, 1950.

MARGULIS, Mário - Contradicỗes na Estructura Agrária e Transferências de Valor. Ed. Jornadas 90. El Colegio de México. 1979.

MARTINE, George et alii - A Evolução do Emprego no campo. Projeto Impacto Social do Desenvolvimento/OIT. 1985.

MARX, Karl - El Capital. Critica de la economia política. Vol. I, II e III. Fondo de Cultura Econômica. 1973.

MARX, Karl - Libro I, Capitulo VI (Inédito). Siglo XXI, 1977.

MENDONÇA DE BARROS, J.R. -- "A Agricultura Brasileira e o Problema da Produção de Alimentos". In: Pesquisa e Planejamento Econômico 8 (3), 1978.

MULLER, Geraldo - "Agricultura e Alimentação no Brasil. 1965-1975". (mimeo).

MULLER, Geraldo - Agricultura e Industrialização no Campo. In: Revista de Economia Pol/tica. Vol. 2. N. 6. 1982.

MONTALVO VIDAL, Norma - "Agricultura $Y$ Reproducción de la Fuerza de Trabajo". Tese de Doutorado em Economia. UNAM/México, 1986.

ONU - "El estado mundial de la agricultura y la alimentación". Roma, 1979 y 1982.

PAULILO, Ma. Ignés - "Crédito Agrícola e Pequena Produção". Trabalho apresentado ao XI Encontro Anual da ANPOCS, 1987.

REVISTAS - Polftica de Garantia de preços mínimos, CFP/MA.

SAAVEDRA DURÃO, Jorge Eduardo et atii - Pesquisa sobre força de trabalho agr ícola em regióes de fronteiras. Relatório Final. Convênio FINEP/INAN/ FASE. 1979.

SILVA, Sérgio - Formas de Acumulação e Desenvolvimento do Capitalismo no Campo. In: PINSKY, Jaime (Org.) Capital e Tabalho no Campo. Ed. Hucitec, São Paulo.

SORJ, Bernardo - Estado e Classes Sociais na Agricultura Brasileira. Zahar Editores, Rio de Janeiro, 1980.

SORJ, B e WILKINSON, J,. - Processos sociais e formas de produção na Agricultura brasileira. In: Sociedade e Polftica no Brasil pós-64. Ed. Brasiliense. 
SORJ, E. WILKINSON, J. - Agroindústrias, Polftica Pública e Estruturas SócioRurais: Análises recentes sobre a Agricultura. Rev. de Economia Pol/tica. Vol. 5. No 4. Out/Dez. 1985.

SORJ, Bernardo - Camponeses e Agroindústria. Zahar, Ed. 1982.

SOUZA, Paulo Renato - A determinação dos salários e o emprego nas economias atrasadas Tese de doutorado. UNICAMP, 1980. (Mimeo).

TAVARES DOS SANTOS, José - Colonos do Vinho. Estudo sobre a subordinação do Trabalho Camponês ao Capital. Ed. HUcitec, 1982.

WANDERLEY, Ma. de Nazareth - O Camponês: um trabalhador para o capital. São Paulo. (Mimeo).

WANDERLEY, Ma. de Nazareth - Capital e Propriedade Fundiária. Ed. Paz e Terra. 1979. 